\title{
A geological model for the structure of ridge segments in slow spreading ocean crust
}

\author{
Brian E. Tucholke and Jian Lin \\ Department of Geology and Geophysics, Woods Hole Oceanographic Institution, Woods Hole, Massachusetts
}

Abstract. First-order (transform) and second-order ridge-axis discontinuities create a fundamental segmentation of the lithosphere along mid-ocean ridges, and in slow spreading crust they commonly are associated with exposure of subvolcanic crust and upper mantle. We analyzed available morphological, gravity, and rock sample data from the Atlantic Ocean to determine whether consistent structural patterns occur at these discontinuites and to constrain the processes that control the patterns. The results show that along their older, inside-corner sides, both firstand second-order discontinuities are characterized by thinned crust and/or mantle exposures as well as by irregular fault patterns and a paucity of volcanic features. Crust on young, outside-comer sides of discontinuities has more normal thickness, regular fault patterns, and common volcanic forms. These patterns are consistent with tectonic thinning of crust at inside comers by lowangle detachment faults as previously suggested for transform discontinuities by Dick et al. [1981] and Karson [1990]. Volcanic upper crust accretes in the hanging wall of the detachment, is stripped from the inside-comer footwall, and is carried to the outside comer. Gravity and morphological data suggest that detachment faulting is a relatively continuous, long-lived process in crust spreading at $<25-30 \mathrm{~mm} / \mathrm{yr}$, that it may be intermittent at intermediate rates of $25-40$ $\mathrm{mm} / \mathrm{yr}$, and that it is unlikely to occur at faster rates. Detachment surfaces are dissected by later, high-angle faults formed during crustal uplift into the rift mountains; these faults can cut through the entire crust and may be the kinds of faults imaged by seismic reflection profiling over Cretaceous North Atlantic crust. Off-axis variations in gravity anomalies indicate that slow spreading crust experiences cyclic magmatic/amagmatic extension and that a typical cycle is about $2 \mathrm{~m} . y$. Iong. During magmatic phases the footwall of the detachment fault probably exposes lower crustal gabbros, although these rocks locally may have an unconformable volcanic carapace. During amagmatic extension the detachment may dip steeply through the crust, providing a mechanism whereby upper mantle ultramafic rocks can be exhumed very rapidly, perhaps in as little as $0.5 \mathrm{~m} . y$. Together, detachment faulting and cyclic magmatic/amagmatic extension create strongly heterogeneous lithosphere both along and across isochrons in slow spreading ocean crust.

\section{Introduction}

The axes of mid-ocean ridges are offset by discontinuities which divide the ocean crust into spreading segments (Figure 1) [Macdonald et al., 1991]. First-order discontinuities in both slow and fast spreading crust are transform faults; they normally offset the ridge axis by $30 \mathrm{~km}$ or more (>0.5-2 m.y. age offset), are oriented in the direction of relative plate motion, and exhibit deep transform valleys. Beyond the ridgetransform intersections (RTIs), the fossil transform zones occur as well defined fracture valleys that trace the history of relative plate motion for tens of millions of years [Menard and Atwater, 1968; Fox et al., 1969; Tucholke and Schouten, 1988].

Second-order discontinuities have smaller offsets, ranging down to $<10 \mathrm{~km}$. In fast spreading crust they appear as overlapping spreading centers, but on slow spreading ridges they are developed as deep bathymetric depressions. Crustal morphology in these depressions differs significantly from that of normal transform faults. Structures oblique to trends of both

Copyright 1994 by the American Geophysical Union.

Paper number 94JB00338.

0148-0227/94/94JB-00338\$05.00 the discontinuities and the spreading axes are common [Searle and Laughton, 1977], and adjacent spreading axes often overlap, with crustal ridges or septa cutting across the discontinuities at high angles [Phillips and Fleming, 1977; Purdy et al., 1990]. Off-axis, the traces of these discontinuities are moderately developed bathymetric valleys which contain a series of crustal depressions. The traces also show a variety of orientations which, although generally symmetrical about the rift axis, may not follow directions of relative plate motion. In slow spreading crust the traces can persist for $10 \mathrm{~m}$.y. or more [Tucholke and Schouten, 1988; Sloan and Patriat, 1992].

Taken together, first- and second-order discontinuities create a fundamental along-axis segmentation of slow spreading ridges, roughly every $50 \pm 30 \mathrm{~km}$, which is expressed by largescale crustal ridge-and-trough morphology that trends across isochrons (Figure 1). Finer-scale, higher-order segmentation also may occur, perhaps being manifested by small offsets of volcanic ridges and by individual volcanoes within the rift valley [Macdonald et al., 1991]. However, these small-scale features represent short-lived ( $<10^{5}$ years) geologic phenomena, and they are not known to create coherent morphologic patterns which can be traced off-axis. Only slow spreading ridge segments bounded by first- and second-order discontinuities are further considered in this paper. 


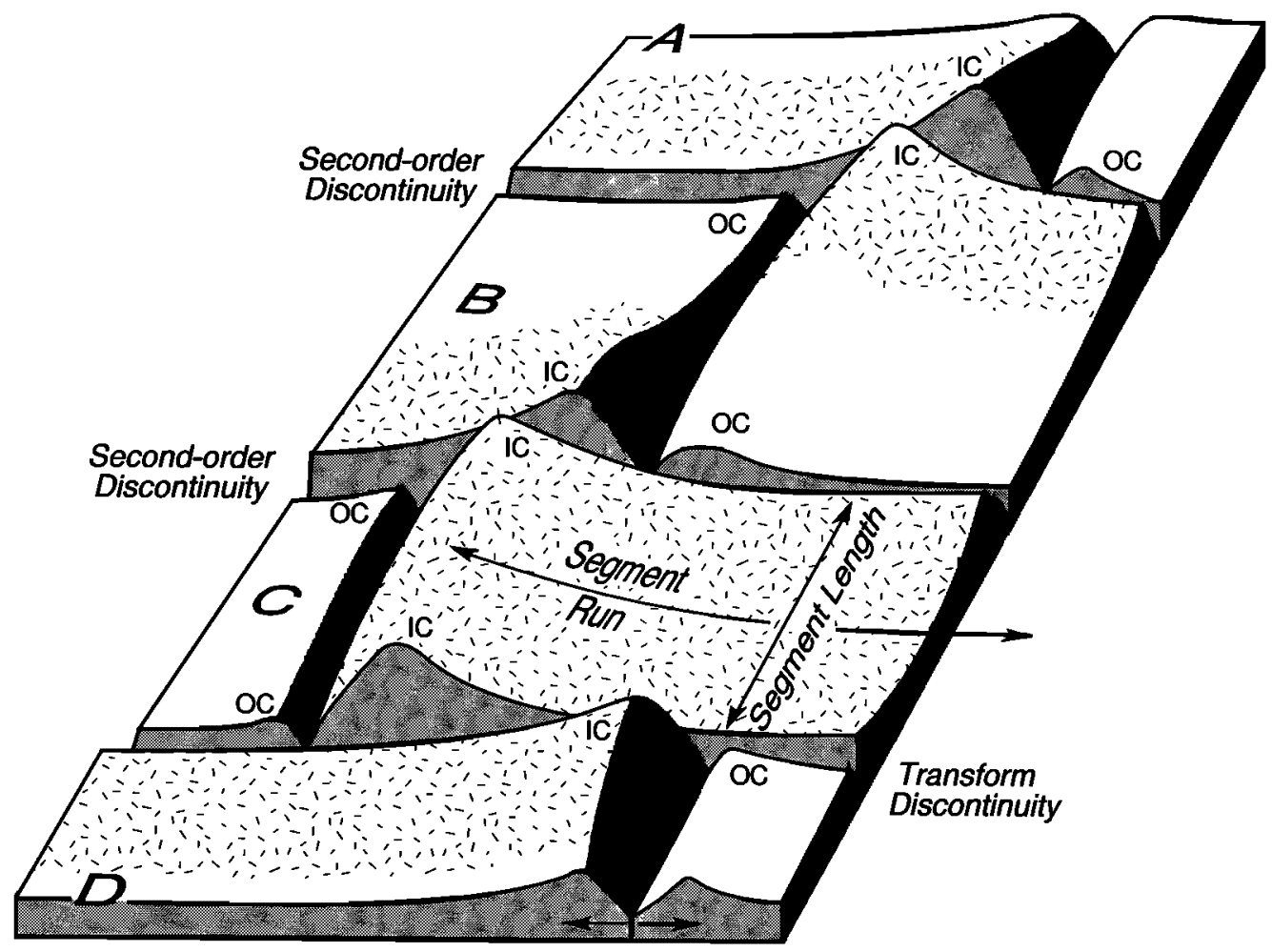

Figure 1. Sketch of segmented slow spreading ocean crust offset by right-stepping second-order discontinuities and a left-stepping transform discontinuity. IC, inside corner; OC, outside corner. IC crust is patterned. The along-isochron dimension of a spreading segment historically bas been termed "segment length". We use the term "segment run" in reference to the typically longer, cross-isochron dimension.

The origin of ridge segmentation has been attributed to the formation of spreading cells above relatively uniformly spaced Rayleigh-Taylor instabilities in the melt zone of the subaxial asthenosphere [Whitehead et al., 1984; Crane, 1985; Lin et al., 1990]. In this model, each spreading segment is thought to mark the locus of a rising and melting mantle diapir. To the extent that the melting anomalies along the plate boundary are stable with respect to a deeper, asthenospheric reference frame, the off-axis traces of nontransform discontinuities may record the absolute motion of the plate boundary [Schouten et al., 1987; Tucholke and Schouten, 1988]. However, the along-axis length of segments bounded by nontransform discontinuities can expand or shrink on -10 m.y. timescales [Sloan and Patriat, 1992; Pockalny and Gente, 1992]. Thus oblique off-axis traces of the discontinuities may reflect development or demise of the spreading segments rather than plate motion. Furthermore, oblique spreading segments have been observed to migrate in different directions on a single plate boundary [Müller and Roest, 1992], suggesting that at least some of the melting anomalies are not stably located.

Mutter and Karson [1992] presented an alternate hypothesis for the origin of segmentation on slow spreading ridges. They suggested that segmentation is mechanically controlled by the locations of detachment faults and intervening accommodation zones where extensional strain is transferred from one detachment fault to another. (Detachment faults, as defined by Davis and Lister [1988, p. 136] have "low angle of initial dip, subregional to regional scale of development, and large translational displacements, certainly up to tens of kilometers in some instances"). In Mutter and Karson's model, mantle upwelling affects the thermal structure of segments and thus the local patterns of brittle/ductile deformation, but it is a consequence, not a cause, of the plate boundary configuration.

At the intersection of a ridge axis with a first- or secondorder discontinuity, an inside corner (IC) is formed in the bight between the spreading axis and the active discontinuity, and an outside corner (OC) occurs on the other side of the spreading axis, next to the inactive trace of the discontinuity (Figure 1). It has been recognized for a number of years that there is an asymmetry in elevation between inside and outside corners in slow spreading crust [Collette, 1986; Severinghaus and Macdonald, 1988]. The inside corners are higher, and they tend to create "transverse ridges" that extend off-axis along the older sides of discontinuities. Over the along-isochron length of spreading segments, the surface of the ocean crust tends to slope downward from inside corner to outside corner, provided that a segment has offsets of similar sense at both ends (segment B, Figure 1). If the direction of offset reverses at the end of a segment (segment C, Figure 1), then the entire segment on one side of the spreading axis is preferentially elevated, and on the other side it is depressed.

Asymmetry in crustal composition of inside and outside corners also has been observed, notably at the eastern RTI of the Kane Fracture Zone in the North Atlantic [Karson and Dick, 1983, 1984]. The inside corner exposes plutonic (lower crustal, generally gabbroic) rocks and mantle ultramafics (e.g., peridotites, serpentinites), whereas the outside corner is uniformly covered by basalts. The IC exposure of gabbros and serpentinites has been attributed by Dick et al. [1981], Brown 
and Karson [1988], and Karson [1990] to the presence of a low-angle normal fault (detachment fault) that dips from the inside corner beneath the spreading axis during phases of amagmatic extension. More generally, the exposure of plutonic and ultramafic rocks is a well known phenomenon in numerous transform discontinuities of both the Atlantic and Indian Oceans [e.g., Bonatti, 1968; Engel and Fisher, 1975; Prinz et al., 1976]. The vast majority of these rocks has been recovered from the active transform valleys, both walls of which are generated at inside corners.

The above observations of crustal composition indicate that there are systematic geologic differences between IC and OC crust at first-order discontinuities, and the observations of IC crustal elevation further suggest that these patterns extend to second-order discontinuities. In this paper we systematically investigate both first- and second-order discontinuities in slow spreading ocean crust by examining the following properties: crustal elevation, gravity field, crustal composition, fine-scale volcanic morphology, and fault patterns. The results show consistent patterns for both first- and secondorder discontinuities that allow us to develop a general model for the geologic structure of ridge segments in slow spreading ocean crust. We also discuss observed effects of cyclicity in magmatic and amagmatic crustal extension that create off-axis variability in the oceanic crustal record. We do not address relations between segmentation and the observed magnetic field in this paper. These relations are complex because crustal magnetization is affected by variations in tectonism and magmatism and because the relative contributions of upper versus lower crustal magnetization to the total magnetic field are uncertain [e.g., Pariso and Johnson, 1993]; a separate manuscript [M.A. Tivey et al., unpublished data, 1993] will address this topic.

\section{Observations at First- and Second-Order Discontinuities}

\section{Crustal Elevation}

Severinghaus and Macdonald [1988] studied the asymmetry between crustal elevations at inside versus outside corners at 57 intersections of ridge axes with first- and second-order discontinuities in the Atlantic and Pacific Oceans. They found that inside corners are consistently higher than outside corners in slow spreading crust. Asymmetry in elevation ranged from about $400 \mathrm{~m}$ to $2500 \mathrm{~m}$ and averaged about $1000 \mathrm{~m}$. No correlation was observed between elevation asymmetry and spreading rate or magnitude of offset (age or distance), but there is a correlation between asymmetry and depth of rift valley (Figure 2).

Severinghaus and Macdonald [1988] also observed that inside corners tend to lie above the normal crustal age-depth curve for ocean crust [Parsons and Sclater, 1977], and they suggested that within a few million years the crust subsides to normal depths. This observation would indicate that dynamic uplift contributes to the elevation of inside corners. There are few detailed off-axis records of crustal depth available to evaluate this idea. Data from the Kane Fracture Zone [Tucholke and Schouten, 1988] suggest that IC crust starts well above the age-depth curve and initially subsides at faster-than-normal rates. However, other data from the North Atlantic [Collette, 1986] and the Indian Ocean [Dick et al., 1991] show that IC crust retains anomalous elevation for tens of million years off

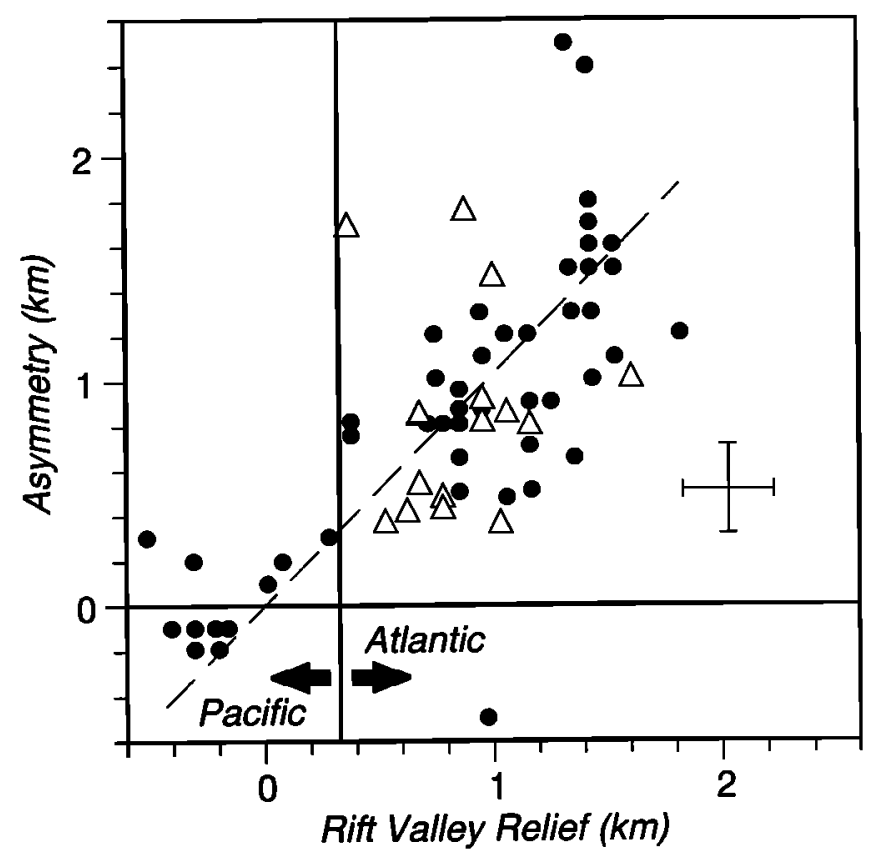

Figure 2. Plot of asymmetry in inside/outside corner elevation versus rift valley relief, adapted from Severinghaus and Macdonald [1988]. Approximate error bars are shown. Triangles denote new data for 15 IC/OC pairs, derived from Sea Beam maps of Purdy et al. [1990] for the Mid-Atlantic Ridge axis between Kane and Atlantis fracture zones.

axis. Thus both a dynamic and a static component appear to contribute to creation and maintenance of excess elevation at inside corners.

Two kinds of dynamic uplift have been proposed to create high inside comers. In one, the driving forces responsible for formation of the median valley and flanking rift mountains uplift the inside corner. IC uplift exceeds that of $O C$ crust because the mechanical strength of the active discontinuity bordering the inside corner is less than that of the inactive trace of the discontinuity [Kuo et al., 1984; Severinghaus and Macdonald, 1988]. A second explanation, proposed by Bercovici et al. [1992], is that the excess crustal elevation may be generated by viscoelastic rebound accompanying corner flow of the lithosphere beneath active discontinuities.

Isostatic effects also have been invoked to explain both IC uplift and continued IC elevation away from the ridge axis. Collette [1986], for example, observed that topographic depression of the valley in an active discontinuity often is greater than that in the inactive trace. When isostatic rebound of this depressed crust occurs, rebound of the coupled IC crust is predicted to be greater than rebound at the outside corner [ $J$. Lin and J.Y. Chen, Subsurface and surface loadings on the oceanic lithosphere at the northern Mid-Atlantic Ridge, submitted to Geophysical Research Letters, 1993]. IC elevation also may be caused by serpentinization of ultramafic rocks at discontinuities; serpentinization reduces the bulk density of the lithosphere and may lead to diapirism or isostatic uplift [Bonatti, 1976]. In any of these cases, once IC crust spreads past the active offset, it becomes better coupled to OC crust on the opposite side of the discontinuity. Thus excess relative elevation of IC crust tends to be locked into the lithosphere on the ridge flanks. 


\section{Gravity Field}

A number of detailed surveys have acquired gravity data along the crest of the Mid-Atlantic Ridge [Kuo and Forsyth, 1988; Lin et al., 1990; Blackman and Forsyth, 1991; Morris and Detrick, 1991]. These data are closely spaced and are accompanied by detailed bathymetric mapping so that the gravity values can be corrected for three-dimensional (3-D) variations in seafloor topography. In the North Atlantic, Lin et al. [1990] reported the results of a survey $(2-5 \mathrm{~km}$ line spacing) that covered five complete spreading segments and their bounding discontinuities between $28^{\circ} \mathrm{N}$ and $30^{\circ} 30^{\prime} \mathrm{N}$; five of the discontinuities are second-order, and one is the transform of the Atlantis Fracture Zone (Plate 1a). The second-order discontinuities are expressed off-axis by bathymetric valleys that form irregular discordant zones. The Atlantis Fracture Zone exhibits a deep, well defined, and relatively linear trough at the transform and in the adjacent inactive fracture zone valleys.

To reveal density variations beneath the seafloor, the gravity data were reduced to residual gravity anomaly (Plate 1b) [Kuo and Forsyth, 1988; Lin et al., 1990]. The residual gravity anomaly was calculated by removing from the observed free-air anomaly the 3-D effects of seafloor topography and the crust-mantle interface (assuming uniform, 6-km-thick crust), as well as the effects of lithospheric cooling based on the 3-D passive-upwelling model of Phipps Morgan and Forsyth [1988]. Seawater, crustal, and mantle densities of $1.03,2.7$, and $3.3 \mathrm{Mg} \mathrm{m}^{-3}$, respectively, were assumed.

The residual gravity anomaly shows clear banding across the ridge axis, and this banding correlates closely with ridge segmentation. Inside corners at second-order discontinuities consistently exhibit residual gravity highs of $20-40 \mathrm{mGal}$ (red arrows), and anomalies at inside corners of the Atlantis transform reach $40-50 \mathrm{mGal}$. The margins of these gravity highs commonly extend beneath the axes of the bounding discontinuities, and they locally impinge on the flanks of adjacent outside corners. In contrast, $O C$ crust and segment centers have a much reduced residual gravity anomaly, typically 5-25 $m G a l$. The resulting asymmetry in IC versus $O C$ residual gravity anomaly, whether compared across the spreading axis or only within a segment on one side of the axis, averages $10-20$ $\mathrm{mGal}$ and locally reaches $35 \mathrm{mGal}$. This asymmetry skews the gravity anomalies clockwise from a ridge-orthogonal direction in locations where discontinuities offset the rift valley right-laterally (red arrows, Plate $1 \mathrm{~b}$ ). The pattern of gravity highs on IC crust and gravity lows on $O C$ crust continues offaxis to the limits of the survey, notably along the Atlantis Fracture Zone (FZ).

A similar pattern of residual gravity anomalies is observed in the vicinity of the TAG area on the Mid-Atlantic Ridge axis at $25^{\circ}$ to $27^{\circ} \mathrm{N}$ (Plate 2 and Figure 3). In this area, three com- plete ridge segments and their bounding second-order discontinuities were surveyed with a narrow beam echo-sounding system and gravimeter at a line spacing averaging about $10 \mathrm{~km}$ [Rona and Gray, 1980; Zervas et al., 1990]. The skewed banding of gravity anomalies across discontinuities at the ridge axis is clearly expressed, and bands of residual gravity highs and lows follow IC and $O C$ crust, respectively, for at least 100 km off-axis. Segment centers, like OC crust, tend to have low residual gravity anomalies. IC and $O C$ residual gravity anomaly values typically differ by $15-25 \mathrm{mGal}$ (Figure 3 ). The bands of gravity anomalies also show significant internal variability along the run of a segment, with local, closed, relative highs and lows that differ by about 5-15 $\mathrm{mGal}$.

Asymmetries in IC/OC residual gravity anomalies also appear at other locations in the Atlantic Ocean where gravity and bathymetry have been mapped in detail. In the MARK area south of the eastern RTI of Kane Fracture Zone [Morris and Detrick, 1991], the gravity field is asymmetric but the asymmetry is reduced compared to the examples cited above; the IC residual gravity anomaly averages about $10 \mathrm{mGal}$ higher than that over $O C$ crust near the RTI. Stronger asymmetry is observed at a second-order discontinuity farther south in the MARK area $\left(23^{\circ} 15^{\prime} \mathrm{N}\right)$, where residual gravity anomalies over IC crust exceed those over $O C$ crust by $10-20 \mathrm{mGal}$. In residual gravity maps of the South Atlantic [Kuo and Forsyth, 1988], two transform faults and three second-order discontinuities also show similar patterns of asymmetry; the IC residual gravity anomalies vary widely but range $10-50 \mathrm{mGal}$ higher than their OC counterparts. With the exception of a second-order discontinuity at $33^{\circ} 35^{\prime} \mathrm{S}$, however, the IC/OC gravity asymmetry generally is less pronounced than in the North Atlantic.

The observed variations in residual gravity anomaly are thought to result from variations in density (i.e., temperature, composition) of the upper mantle, variations in thickness or density of the ocean crust, or some combination of both [Kuo and Forsyth, 1988; Lin et al., 1990]. Theoretical modeling which is consistent with available data suggests that the contribution of upper mantle thermal structure to the gravity anomalies is very limited. Lin and Phipps Morgan [1992] showed that if mantle upwelling is driven only by plate separation, then large gravity anomalies should be limited to large-offset transforms (>2 m.y. offset); at smaller, secondorder discontinuities ( $<1$ m.y. offset) only small anomalies are predicted. Sparks et al. [1993] extended the passive-upwelling model to include buoyancy-driven mantle upwelling. They showed that with focused upwelling, along-axis changes in the gravity field are strongly dominated by increased crustal thickness which results from enhanced melting beneath segment midpoints, rather than by mantle-density variations.

The asymmetry of the gravity field across the ridge axis also is difficult to explain only by variations in upper mantle

Plate 1. (a) Bathymetry of the Mid-Atlantic Ridge axis near Atlantis Fracture Zone (FZ) in the North Atlantic Ocean, from Purdy et al. [1990]. Bold lines mark the rift axis, and dashed lines follow axes of maximum depth (AMD) along traces of second-order discontinuities; the AMD is an objective approximation of the former position of the plate boundary. (b) Residual gravity anomalies for the same region, with ridge axis and discontinuities located as in (a). Note residual gravity highs at inside corners (arrows). (c) Relative crustal thickness calculated from residual gravity anomalies. Note thin crust beneath inside corners (arrows). (d) Sketch map of ridge segmentation and major fault zones. Long, relatively linear fault zones commonly cover the full along-isochron length of segments, and more irregular fault patterns tend to occur at inside corners, particularly along Atlantis FZ. 


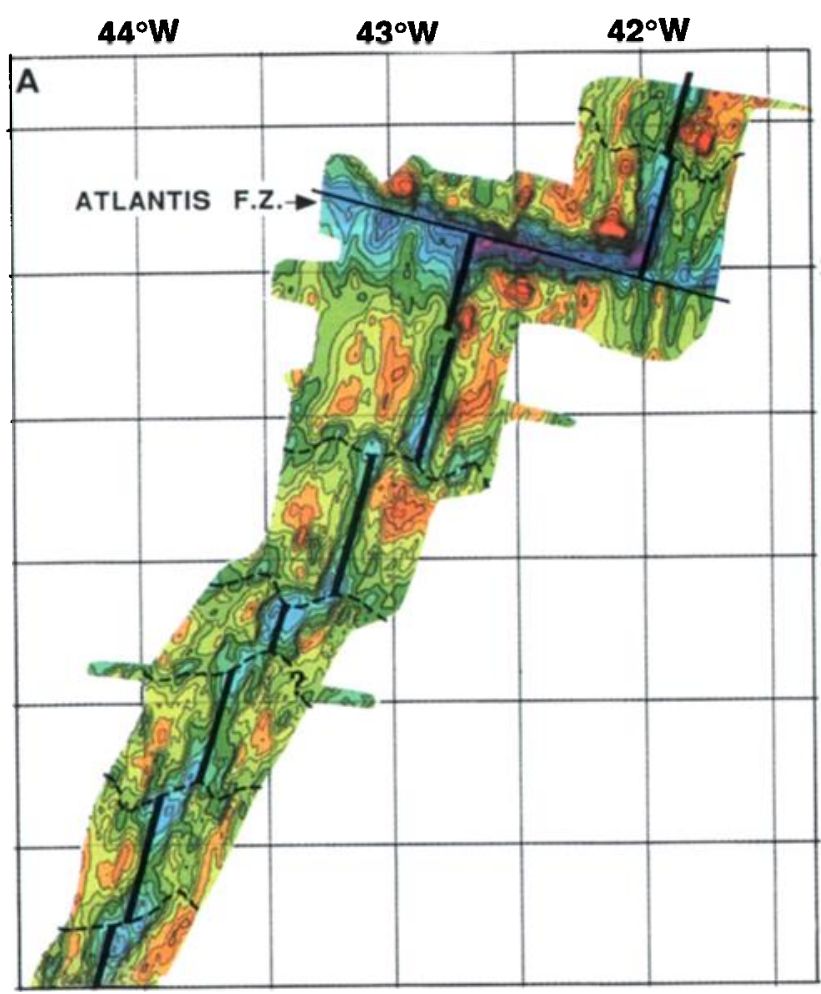

BATHYMETRY

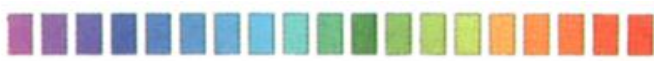

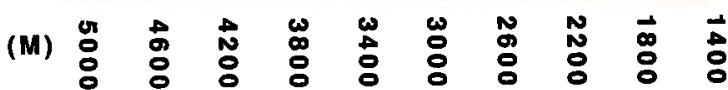

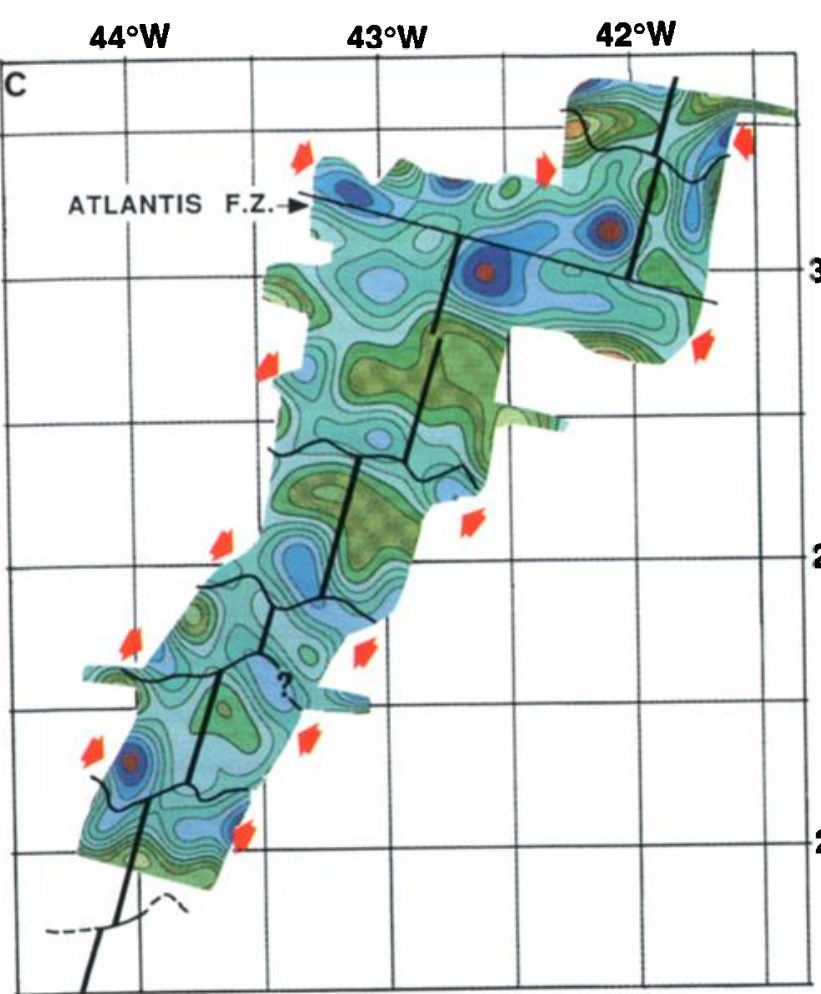

CRUSTAL THICKNESS

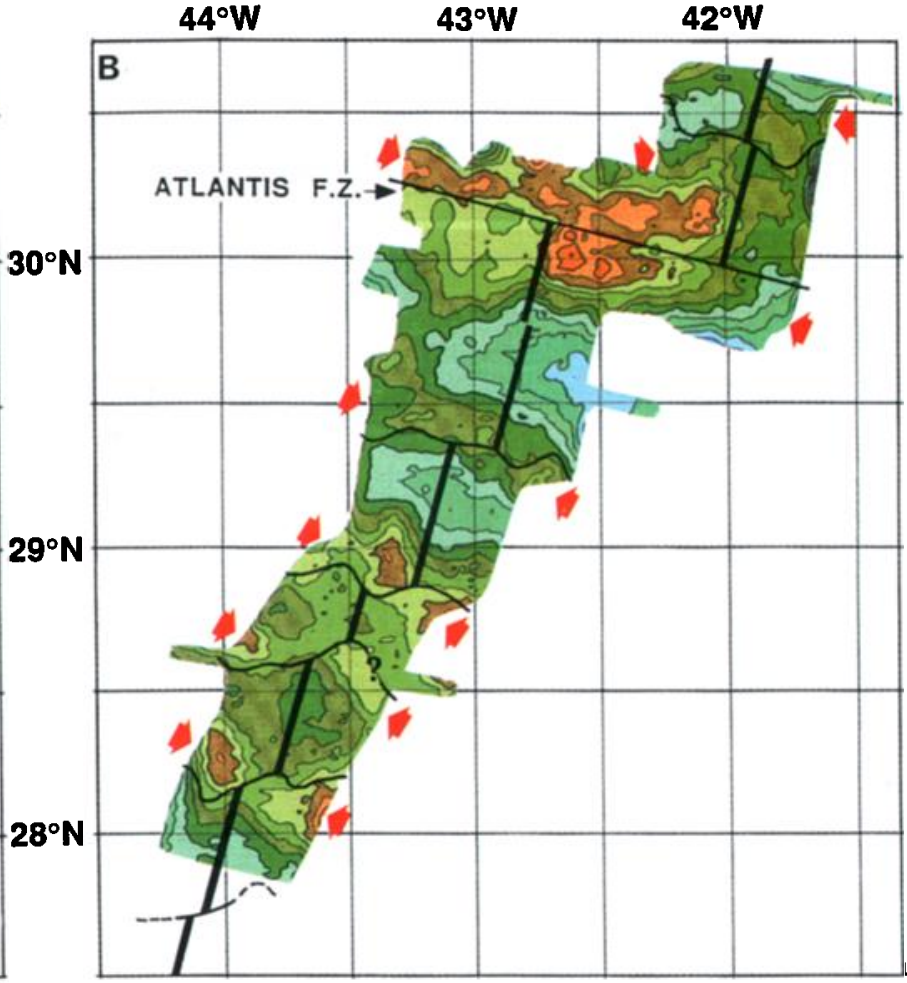

RESIDUAL GRAVITY ANOMALY

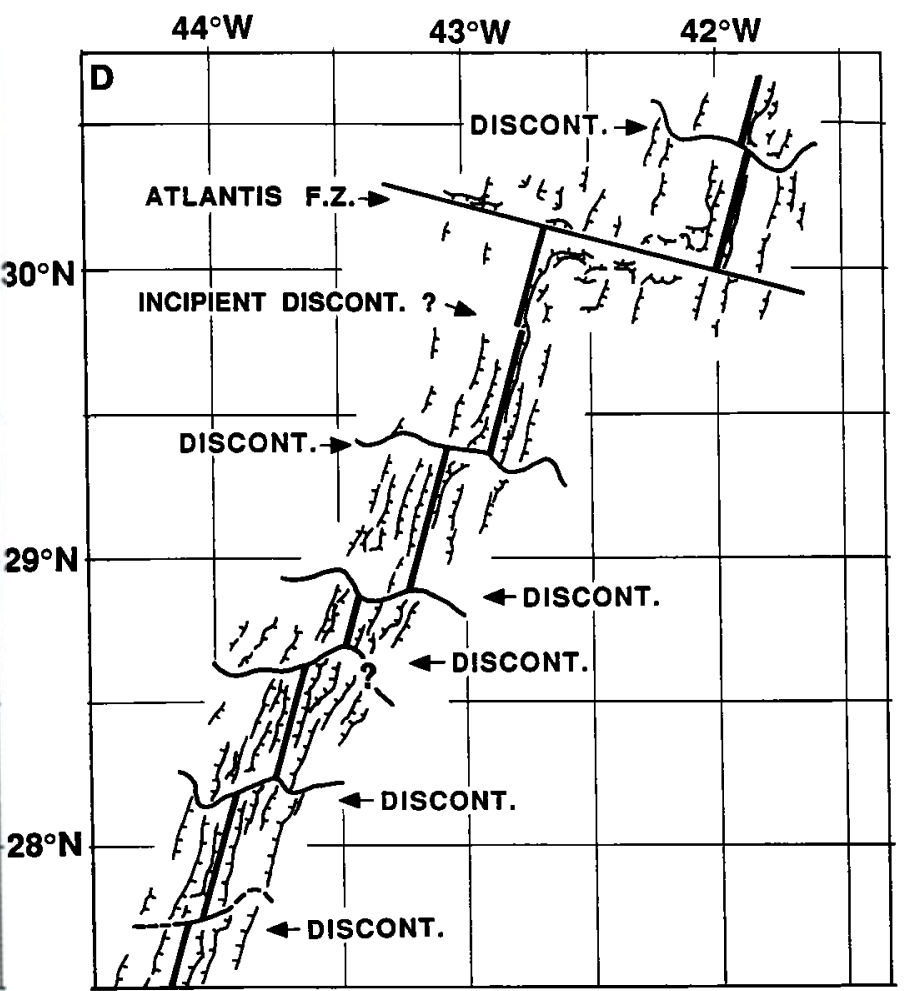

TECTONIC PATTERNS

(KM) $\dot{\omega}$ i $\doteq 0-N$ w 


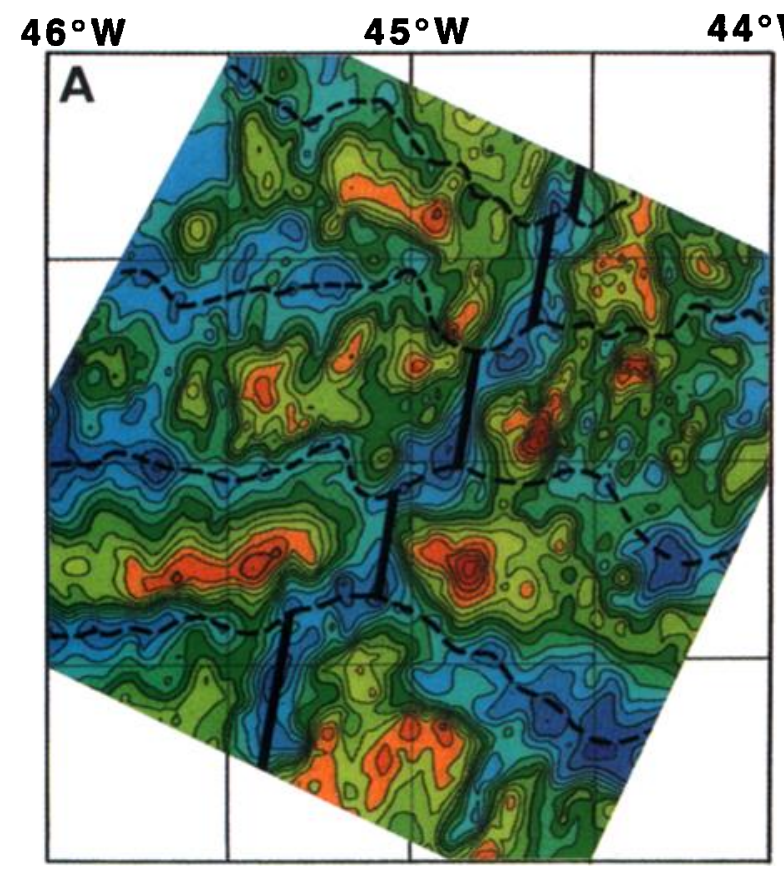

BATHYMETRY

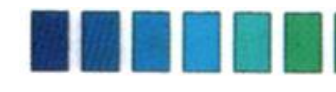

(M)

$\begin{array}{lllllll}\omega & N & \omega & N & N & \vec{N} & \vec{A} \\ 0 & \mathbb{0} & 0 & 0 & N & 0 & 0 \\ 0 & 0 & 0 & 0 & 0 & 0 & 0 \\ 0 & 0 & 0 & 0 & 0 & 0 & 0\end{array}$

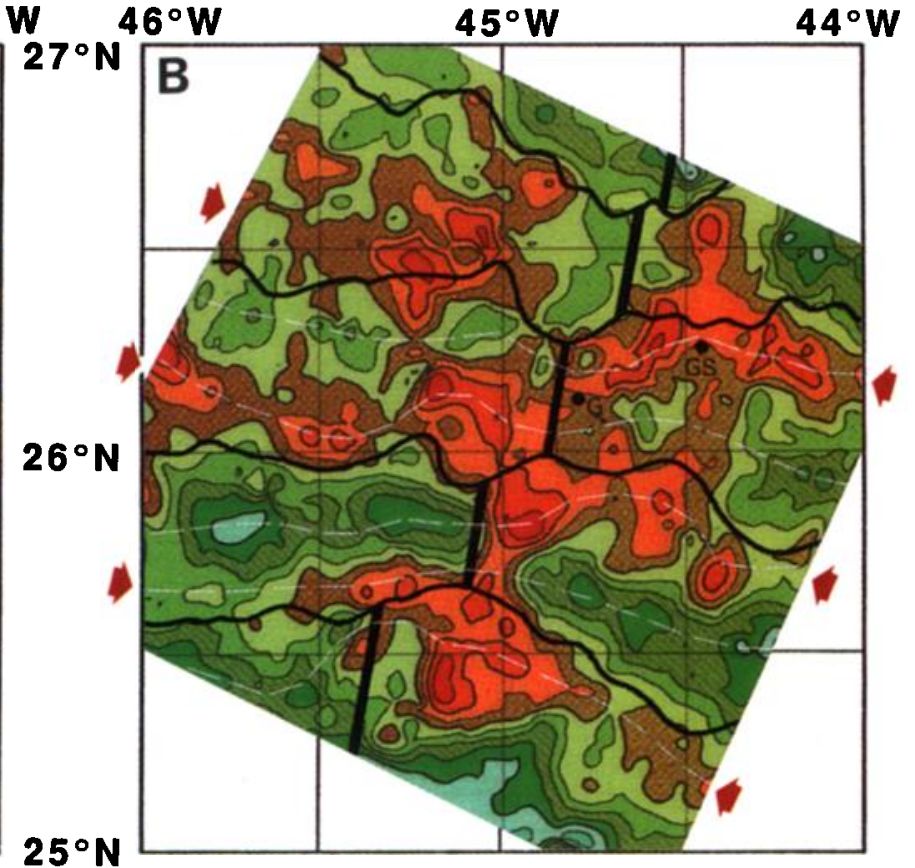

RESIDUAL GRAVITY ANOMALY

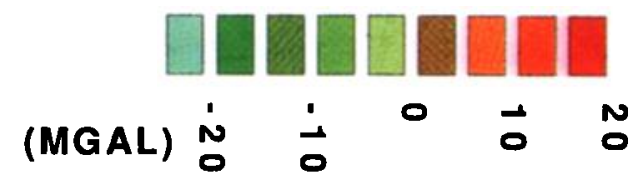

Plate 2. (a) Bathymetry of the Mid-Atlantic Ridge axis in the vicinity of the TAG area [from Rona and Gray, 1980]. The ridge axis and discontinuities are marked as in Plate 1. (b) Residual gravity anomalies of the same region, marked as in Plate 1 [Zervas et al., 1990]. Note the bands of residual gravity highs (arrows) and lows extending off-axis along IC and OC crust, respectively, and the variation of anomaly values within each of the bands. Fine white lines locate axes of gravity highs and lows profiled in Figure 3 . $G$ and $S$ identify dredged gabbros and serpentinites [Tiezzi and Scott, 1980].

density. If the gravity anomalies are attributed to temperature or compositional differences in the mantle, then some process is required in the subaxial asthenosphere to partition cooler, denser upper mantle to inside corners and hotter, less dense upper mantle to outside corners on the opposite side of the rift axis. We know of no reasonable physical mechanism to achieve such partitioning.

The strong asymmetry in IC/OC residual gravity anomaly thus appears best to be explained by differences in crustal thickness and/or density. It seems unlikely that crustal density can be the sole control; it is implausible that a mechanism exists to generate IC and $O C$ crust with similar thicknesses, but with differing densities, in the absence of crustal thinning. We therefore hypothesize that the high residual gravity values at inside corners are caused by crustal thinning and consequent elevation of the Moho; accompanying increases in average crustal density are permissible but are not required.

Relative crustal thicknesses along the Mid-Atlantic Ridge near the Atlantis $\mathrm{FZ}$ were calculated using a reference crustal thickness of $6 \mathrm{~km}$ and a crust/mantle density contrast of 0.6 $\mathrm{Mg} \mathrm{m}^{-3}$ (Plate 1c) [Lin et al., 1990]. The total range of calculated crustal thicknesses is $6 \mathrm{~km}$, with minimum values consistently occurring at IC crust. IC crust averages 2 to $3 \mathrm{~km}$ thinner than crust at adjacent outside corners, both at the Atlantis transform and at the second-order discontinuities to the south. However, relative crustal thicknesses of both inside and outside corners at the Atlantis $\mathrm{FZ}$ are a kilometer or more less than those around the second-order discontinuities. The thermal edge effect of this large transform [Fox and Gallo, 1984] may have reduced the magma budget and the overall crustal thickness compared to the smaller-offset discontinuities farther south.

As noted earlier, the residual gravity highs observed along IC crust commonly extend well beneath the axes of the adjacent first- and second-order discontinuities, implying that the discontinuities themselves are floored by thin ocean crust (Plate 1c). This observation is consistent with previous gravity studies of both transform valleys and second-order discontinuities which concluded that crust in discontinuities is anomalously thin [Louden and Forsyth, 1982; Prince and Forsyth, 1988; Kuo and Forsyth, 1988; Lin et al., 1990; Morris and Detrick, 1991; Blackman and Forsyth, 1991]. It also agrees with seismic refraction experiments which have shown that discontinuities typically have reduced crustal thicknesses and/or anomalous seismic velocities [e.g., White et al., 1984; Cormier et al., 1984; Ambos and Hussong, 1986; Minshull et al., 1991; Detrick et al., 1993]. Thin crust 


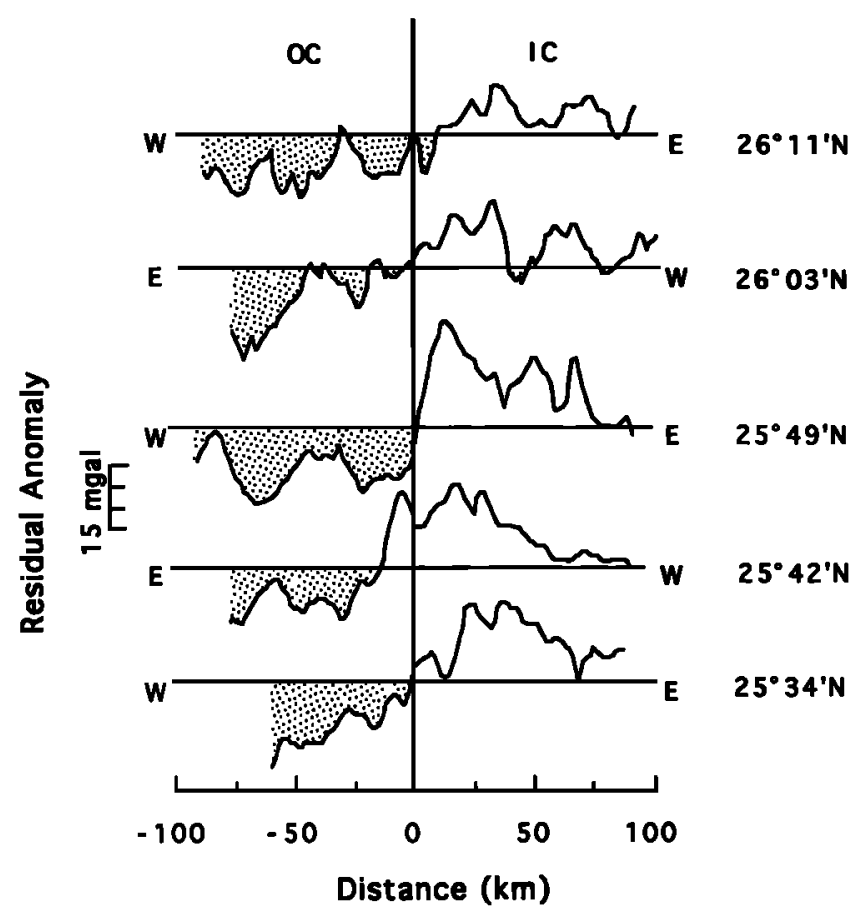

Figure 3. Profiles of residual gravity anomaly along the axes of gravity highs over IC crust and the axes of gravity lows over conjugate $O C$ crust in the TAG area of Plate 2. Latitude labels show where each profile crosses the Mid-Atlantic Ridge axis (vertical line). Note that all profiles are oriented with $O C$ crust on the left. Residual gravity values of $O C$ crust are routinely lower than IC values, suggesting consistently thinner crust along inside corners. beneath ridge axis discontinuities is generally attributed to diminished volcanism caused either by hydraulic head loss as melts intrude along-strike away from magmatic loci near segment centers [Whitehead et al., 1984; Macdonald, 1986] or by accelerated heat loss to the cold truncating lithosphere at the offset [Fox et al., 1980; Fox and Gallo, 1984].

\section{Crustal Composition}

The inference from gravity data that crust at inside corners and in troughs of the adjacent discontinuities is thinner than $O C$ crust can be examined in the results of seafloor sampling throughout the Atlantic Ocean. A thinner, and possibly denser, crustal section should result in increased exposure of plutonic and ultramafic rocks at inside corners. OC seafloor, which from gravity data appears to have a more normal crustal thickness, should be dominated by basaltic rocks and should only rarely expose plutonic or ultramafic sections.

To examine the distribution of rock types in relation to IC/OC tectonic setting, we compiled the results of dredge, drill site, and submersible sample recoveries at 655 stations reported in the literature and in the dredge collection of Woods Hole Oceanographic Institution (Table 1). The recoveries were divided into three categories: (1) Stations recovering only a lower crustal to upper mantle suite of plutonic and ultramafic rocks; the rocks are primarily gabbros and peridotites (peridotites typically $10-90 \%$ serpentinized); (2) stations recovering only an upper crustal suite of volcanic and intrusive igneous rocks, predominantly basalts and subsidiary diabases; and (3) stations recovering a mixed suite of these rocks. We noted only the presence or absence of each rock type at the stations; data generally were not available to quantify relative weights or volumes of rock types. These three categories were further subdivided according to the tectonic setting from which the samples were recovered:

Table 1. Distribution of Rock Types in Dredge, Drill Site, and Submersible Sample Recoveries From Slow Spreading Crust of the Atlantic Ocean

\begin{tabular}{|c|c|c|c|c|}
\hline $\begin{array}{l}\text { Tectonic } \\
\text { Setting }\end{array}$ & $\begin{array}{l}\text { Ultramafic/Plutonic } \\
\text { Rocks Only }\end{array}$ & $\begin{array}{l}\text { Ultramafic/Plutonic } \\
\text { + BasaltDiabase }\end{array}$ & $\begin{array}{c}\text { Basalt/Diabase } \\
\text { Only }\end{array}$ & Totals \\
\hline Inside corners & $\begin{array}{l}142 \\
(38 \mathrm{P}, 80 \mathrm{U}, 24 \mathrm{UP})\end{array}$ & $\begin{array}{l}91 \\
\text { (16 PB, } 1 \text { PD, } 15 \text { PBD, } \\
17 \text { UB, } 3 \text { UBD, } 27 \text { UPB, } \\
1 \text { UPD, } 11 \text { UPBD) }\end{array}$ & $\begin{array}{l}125 \\
(116 \mathrm{~B}, 1 \mathrm{D}, 8 \mathrm{BD})\end{array}$ & $\begin{array}{l}358 \text { IC recoveries, } \\
\text { including } 233 \text { recoveries } \\
\text { of } U / P \text { rocks }(65 \%)\end{array}$ \\
\hline Outside comers & $\begin{array}{l}11 \\
(8 \mathrm{U}, 3 \mathrm{UP})\end{array}$ & $\begin{array}{l}12 \\
\text { (10 UB, } 2 \text { UPB) }\end{array}$ & $\begin{array}{l}109 \\
(105 \mathrm{~B}, 2 \mathrm{D}, 2 \mathrm{BD})\end{array}$ & $\begin{array}{l}132 \text { OC recoveries, } \\
\text { including } 23 \text { recoveries } \\
\text { of U/P rocks (17\%) }\end{array}$ \\
\hline Undetermined & $\begin{array}{l}21 \\
(2 \mathrm{P}, 7 \mathrm{U}, 12 \mathrm{UP})\end{array}$ & $\begin{array}{l}12 \\
(5 \text { PB, } 1 \text { PBD, } 5 \text { UPB, } \\
1 \text { UPBD) }\end{array}$ & $\begin{array}{l}58 \\
(55 \mathrm{~B}, 1 \mathrm{D}, 2 \mathrm{BD})\end{array}$ & $\begin{array}{l}91 \text { undetermined } \\
\text { recoveries, including } 33 \\
\text { recoveries of U/P rocks } \\
(36 \%)\end{array}$ \\
\hline $\begin{array}{l}\text { Special tectonic } \\
\text { setting }\end{array}$ & $\begin{array}{l}23 \\
(4 \mathrm{P}, 17 \mathrm{U}, 2 \mathrm{UP})\end{array}$ & $\begin{array}{l}7 \\
\text { (2 PB, } 2 \text { UB, } 1 \text { UBD, } 2 \text { UPB) }\end{array}$ & $\begin{array}{l}44 \\
(44 B)\end{array}$ & $\begin{array}{l}74 \text { STS recoveries, } \\
\text { including } 30 \text { recoveries } \\
\text { of } U / P \text { rocks }(41 \%)\end{array}$ \\
\hline Totals & $\begin{array}{l}197 \text { recoveries of } \\
\text { only U/P rocks } \\
\text { (30\% of total) }\end{array}$ & $\begin{array}{l}122 \text { recoveries of } U / P+B / D \\
\text { rocks ( } 19 \% \text { of total) }\end{array}$ & $\begin{array}{l}336 \text { recoveries of only } \\
\text { B/D rocks ( } 51 \% \text { of } \\
\text { total) }\end{array}$ & $\begin{array}{l}655 \text { total recoveries, } \\
\text { including } 319 \text { recoveries } \\
\text { of U/P rocks }(49 \%)\end{array}$ \\
\hline
\end{tabular}

Compilation excludes recoveries from seamounts and from drill sites on $>20 \mathrm{Ma}$ crust, excepting plutonic and ultramafic rocks recovered in special tectonic settings (STS). U, ultramafic; P, plutonic; B, basalt; D, diabase. References used for the compilation are available on request from the senior author. 
1. The inside corner group includes crust currently generated at inside corners along the ridge axis, as well as IC crust which extends off-axis along the run of a spreading segment (i.e., along the old side of the ridge axis discontinuity; Figure 1). The IC category is restricted to crust within $30 \mathrm{~km}$ of the axis of maximum depth (AMD) of the bounding discontinuity (approximately half the along-isochron length of an average spreading segment). For segments longer than $60 \mathrm{~km}$, we included samples $>30 \mathrm{~km}$ from the AMD but within the IC half of the segment.

2. The outside corner group includes $O C$ crust both adjacent to the ridge axis and extending off-axis along the run of a segment (i.e., on the young side of the ridge-axis discontinuity).

3. Samples of unknown morphotectonic affinity were recovered where existing bathymetric data are inadequate to define sample location with respect to traces of ridge axis discontinuities. Most samples are from regions where secondorder discontinuities occur. The small offsets and intermittent bathymetric valleys of these discontinuities seldom are clearly defined in any bathymetric maps except those surveyed with multibeam bathymetric systems.

We also assigned plutonic and ultramafic rocks from a number of sample sites to the category of "special tectonic setting". In these environments the tectonism responsible for exposure of the rocks is unrelated to original ridge segmentation. Most of these samples come from Kings Trough, which is thought to be a failed rift [Srivastava et al., 1990]; from the Galicia Bank margin, where peridotites became exposed during continental breakup [Boillot et al., 1989]; from Gorringe Bank, which is a compressional plate boundary [Klitgord and Schouten, 1986]; and from the Puerto Rico Trench or the south wall of Cayman Trough.

Stations recovering plutonic and ultramafic rocks in the Atlantic and Caribbean are shown in Figure 4. The great majority of the samples come from IC crust. However, this reflects sampling bias toward the walls of active discontinuities, both walls of which are inside corners. To correct for this bias, we examined occurrence of plutonic/ultramafic rocks versus occurrence of only upper crustal rocks at both inside and outside corners (Table 1). At inside corners, two thirds of the total recoveries included plutonic and/or ultramafic rocks; in this group, ultramafic rocks were recovered slightly more often than plutonic rocks (163 versus 133 occurrences). At outside corners, in contrast, only $17 \%$ of 132 sample recoveries contain plutonic/ultramafic rocks; ultramafic samples are present in all of this group (23 occurrences), and plutonic rocks are relatively uncommon (five occurrences). From these data it is clear that lower crustal and upper mantle lithologies are sampled much more consistently on IC crust than they are on $\mathrm{OC}$ crust. Although there is uncertainty about the representativeness of recovery by various sampling tools, particularly dredges, it is clear that upper mantle rocks are widely exposed at inside corners. We interpret this to mean that the crustal sections there are thinned, in accordance with the gravity observations noted above. The common occurrence of lower crustal rocks also suggests that the average IC crustal density is higher than that of outside corners. OC crust is dominated by upper crustal lithologies, indicating that relatively thicker and more continuous volcanic sections are present in these settings. This is consistent with the presence of thicker crust inferred from gravity data.

It is noteworthy that at least $58 \%$ of the sample recoveries from inside corners included upper crustal basalts or diabases
(92\% at outside corners). These percentages are minima; the published papers from which the data were derived do not necessarily note corecovery of volcanic or intrusive rocks if deeper crustal and mantle rocks were the subject of study. Conversely, some published papers dealing with the basaltic crust also fail to report coincident recovery of plutonic or ultramafic rocks. These latter rocks, however, generally have been noted in other publications, and any effects caused by their under reporting probably is negligible. Despite these uncertainties, we can safely state that it is not uncommon for an upper crustal carapace to be present on IC crust. The common occurrence of lower crustal and upper mantle lithologies, however, indicates that this carapace must be thin and/or intermittent.

An example of the differentiation of rock types between inside and outside corners is shown in Figure 5 for the area around Kane FZ. The eastern ridge-transform intersection has been extensively studied by dredging, submersible dives, and bottom photography [Karson and Dick, 1983; 1984; Mevel et al., 1991]. These studies have documented that lower crustal gabbros crop out over an area of at least $50 \mathrm{~km}^{2}$ along the east face of the IC high between about $2500 \mathrm{~m}$ and $6000 \mathrm{~m}$ depth. Parts of the crest and west flank of the IC high have basalts exposed at the seafloor, as do the rift valley axis and the outside corner. A well defined neovolcanic basalt ridge with active hydrothermal vents is developed in the center of the rift valley [Karson et al., 1987; Gente et al., 1991]. At the south end of this ridge segment, serpentinites have been dredged [Gente et al., 1989] and sampled by submersible [Karson et al., 1987; Mevel et al., 1991] from the outside corner (west wall of rift valley); this is a clear exception to the observation that outside corners rarely expose deeper lithologies.

Ocean Drilling Program (ODP) Site 670 was drilled on the inside corner of the next segment to the south (Figure 5), and it recovered serpentinites and serpentinized harzburgites [Shipboard Scientific Party, 1988]. Deep Sea Drilling Project (DSDP) Site 395, to the southwest, also recovered serpentinites and gabbros interbedded between basalts at $\sim 160-170$ m subbottom [Shipboard Scientific Party, 1979]. This site was drilled in a depression that can now be recognized as part of an east-west trending bathymetric valley marking the trace of a former second-order discontinuity. The discontinuity became indistinct at about $5 \mathrm{Ma}$, and it is not readily recognizable at the present ridge crest. Offset of magnetic anomalies immediately north and east of Site 395 [Hussong et al., 1979] suggests that the site was drilled on IC crust.

At the western ridge-transform intersection of Kane FZ, gabbros have been reported from submersible dives on the inside corner [Zonenshain et al., 1989] and serpentinites have been dredged there [B. Tucholke and $H$. Dick, unpub. data]. The axis of the rift valley contains a neovolcanic ridge [Karson and Dick, 1983; 1984; Zonenshain et al., 1989] from which extensive dredging has recovered basalts. No samples have been reported from the outside corner. Gabbros and serpentinites have been dredged from the walls on the old, IC sides of the Kane fracture valley both within the transform region and along the inactive fracture valley (Figure 5) [Miyashiro et al., 1969; Dick, 1989].

\section{Fine-Scale Volcanic Morphology}

Hundreds of volcanic cones have been identified in multibeam bathymetric data along the axis of the Mid-Atlantic rift valley between the Kane and Atlantis fracture zones [Smith and 


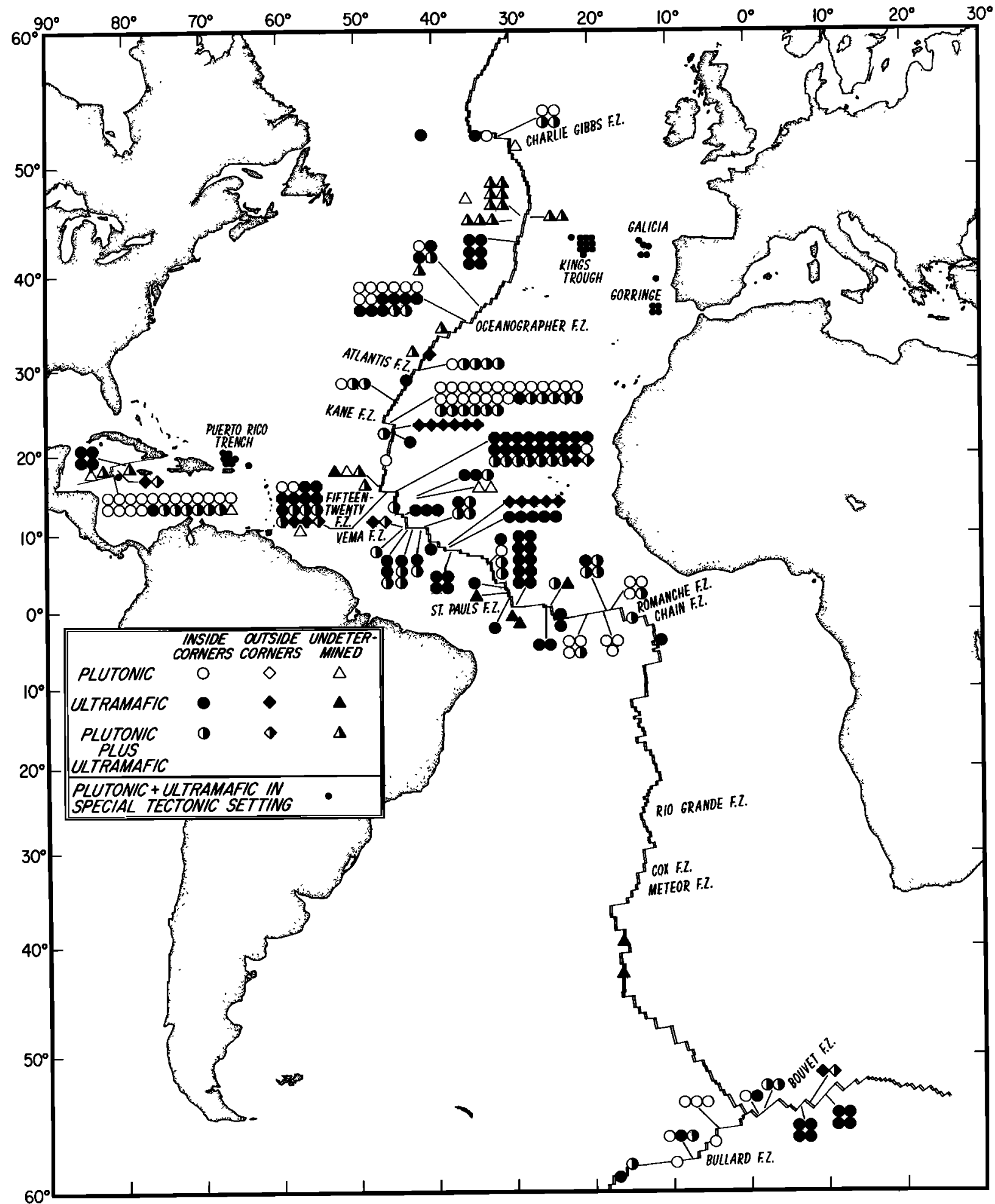

Figure 4. Occurrence of plutonic and ultramafic rocks in dredge, drill site, and submersible sample stations from the Atlantic Ocean. Symbols show composition and tectonic setting; all samples illustrated are from $<20 \mathrm{Ma}$ crust, except those noted for special tectonic settings. Compiled from the published literature and the dredge collection of Woods Hole Oceanographic Institution.

Cann, 1992], and they form a more or less well defined neovolcanic zone in nearly every spreading segment surveyed. This observation suggests that a neovolcanic zone is a common feature along most segments of slow spreading ridges. The processes attending dissection and transport of this volcanic carapace into the rift mountains and ridge flanks are not well understood, but recent, detailed near-bottom surveys suggest that many of these volcanoes may survive faulting well enough to be recognized off-axis [Smith and Cann, 1993].

Multibeam bathymetry and side scan sonar records provide evidence that the volcanic upper crust is better preserved on outside corners than on inside corners. Figure 6 illustrates 


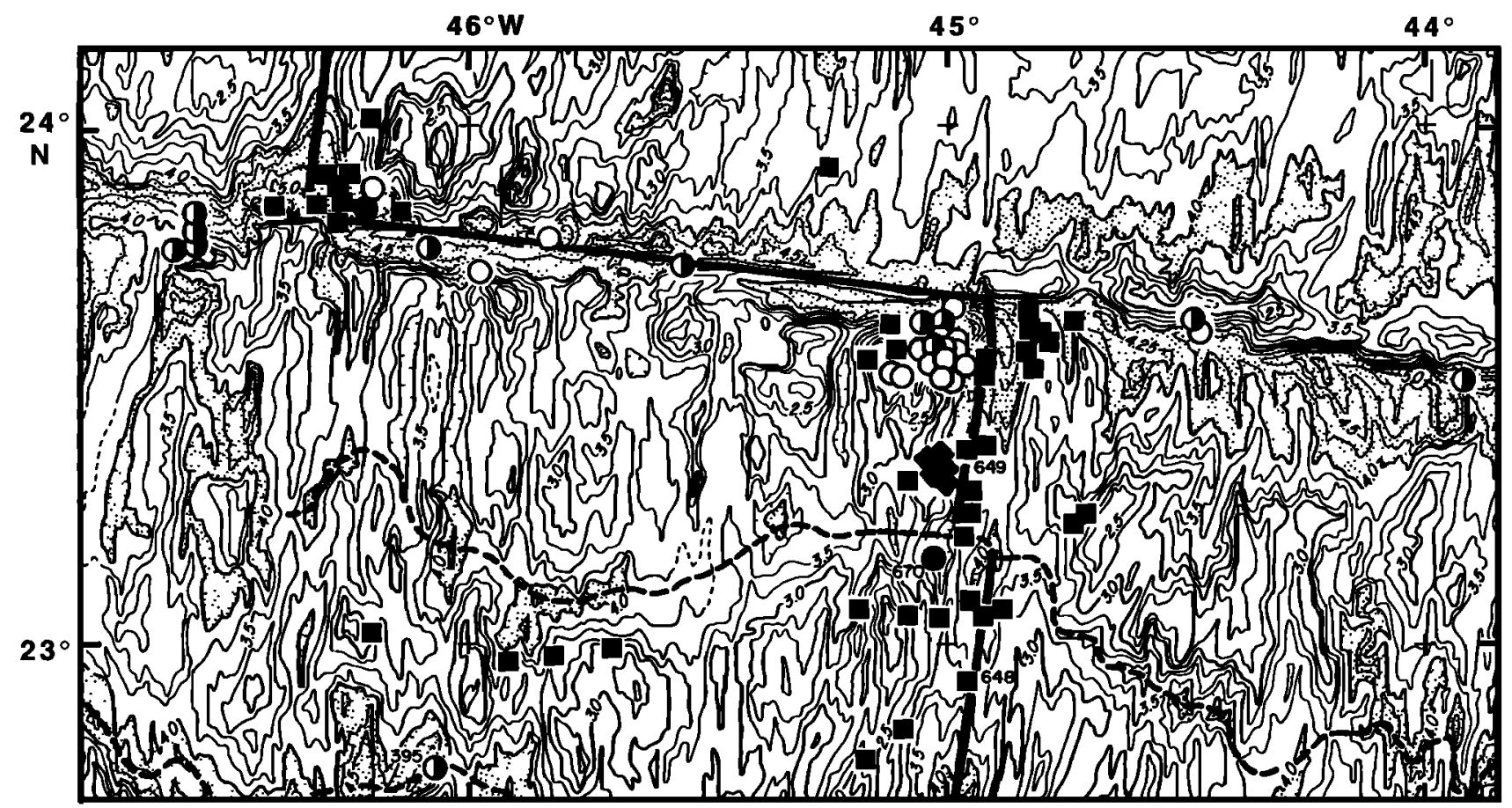

Figure 5. Structure contours on basement around Kane FZ [from Tucholke and Schouten, 1988]. Contour interval is $250 \mathrm{~m}$; depths $>4000 \mathrm{~m}$ are shaded. Symbols show recoveries of plutonic and ultramafic rocks as in Figure 4; recoveries of only basalts are indicated by solid squares. DSDP and ODP drill sites are numbered. Second-order discontinuities and ridge axis are marked as in Plate 1.

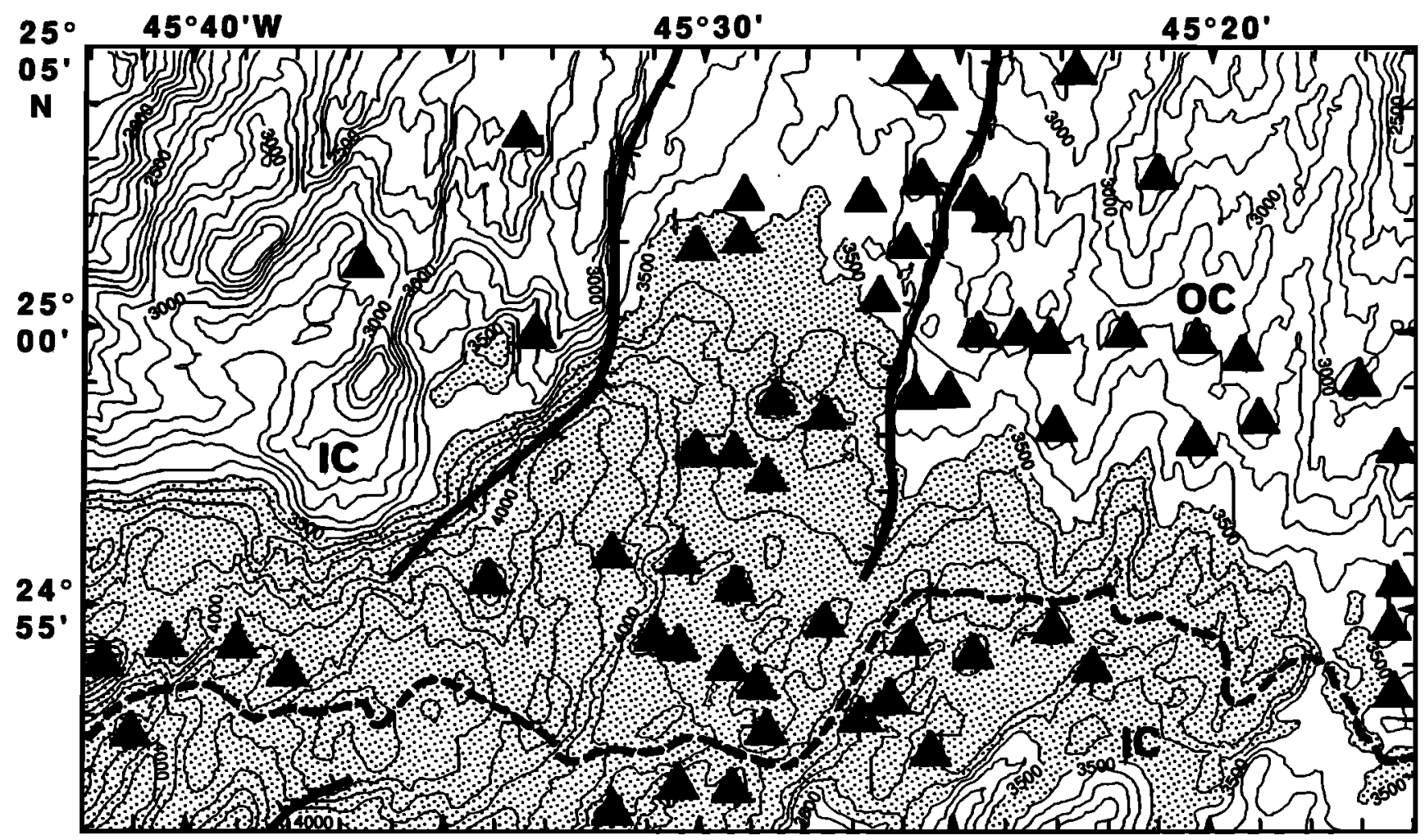

Figure 6. Multibeam bathymetry of an inside/outside corner pair next to a second-order discontinuity at the Mid-Atlantic Ridge axis. Contour interval is $100 \mathrm{~m}$; depths $>3500 \mathrm{~m}$ are shaded. Triangles locate relatively circular volcanic cones identified in $20-\mathrm{m}$ contour data, based largely on work by Smith and Cann [1992, also unpublished data, 1992]. Heavy lines are boundary faults demarcating the inner floor of the rift valley, and the dashed line marks the AMD of the discontinuity. Note that IC crust exhibits blocky morphology and uncommon volcanic cones; OC crust is more lineated, with common volcanic cones. 
this observation for multibeam bathymetric data in the North Atlantic. The OC crust is dominated by ridge-parallel topography and faults, and it exhibits numerous conical features that appear to be small volcanoes. Some of these cones are bounded by steep, linear slopes which parallel the ridge axis and may be normal-fault zones. The volcanoes also populate the rift valley [Smith and Cann, 1992], and they are common within the bathymetric depression that defines the discontinuity between spreading segments. The IC crust has less lineated topography and shows only uncommon occurrences of volcanic cones. Most of the cones on IC crust occur within 3-5 $\mathrm{km}$ of the axis of the discontinuity.

Side scan sonar data show a similar pattern in distribution of volcanic features, as illustrated for the Kane FZ in Figure 7. Along this transform discontinuity the $O C$ crust exhibits abundant evidence of hummocky volcanic terrain and volcanic cones. The volcanoes range in diameter from about 0.5 to nearly $2 \mathrm{~km}$, and they vary from single, isolated cones to clusters. There are no clear-cut examples of faults incising the volcanic features, although common elongation of cones parallel to the faults suggests that their shape has been controlled or modified by faulting. IC crust has a distinctly different character; it shows dominantly blocky, irregularly faulted topography with only rare indications of volcanoes or hummocky volcanic morphology. The few volcanic features observed on IC crust typically occur deep within the fracture valley, close to the axis of the discontinuity.

\section{Fault Patterns}

Detailed studies of fault patterns by submersible observation and in bottom photographs show consistent differences in the nature of faulting at inside and outside corners [Karson and Dick, 1983, 1984; OTTER, 1984]. Direct observations of the basaltic crust at outside corners indicate that faults tend to be steep $\left(70^{\circ}-90^{\circ}\right)$ with throws usually less than a few tens of meters, and the faults locally group to form fault zones of moderate average slope $\left(>30^{\circ}\right)$. Most of the faults face inward toward the rift valley axis and strike parallel to it; backtilting
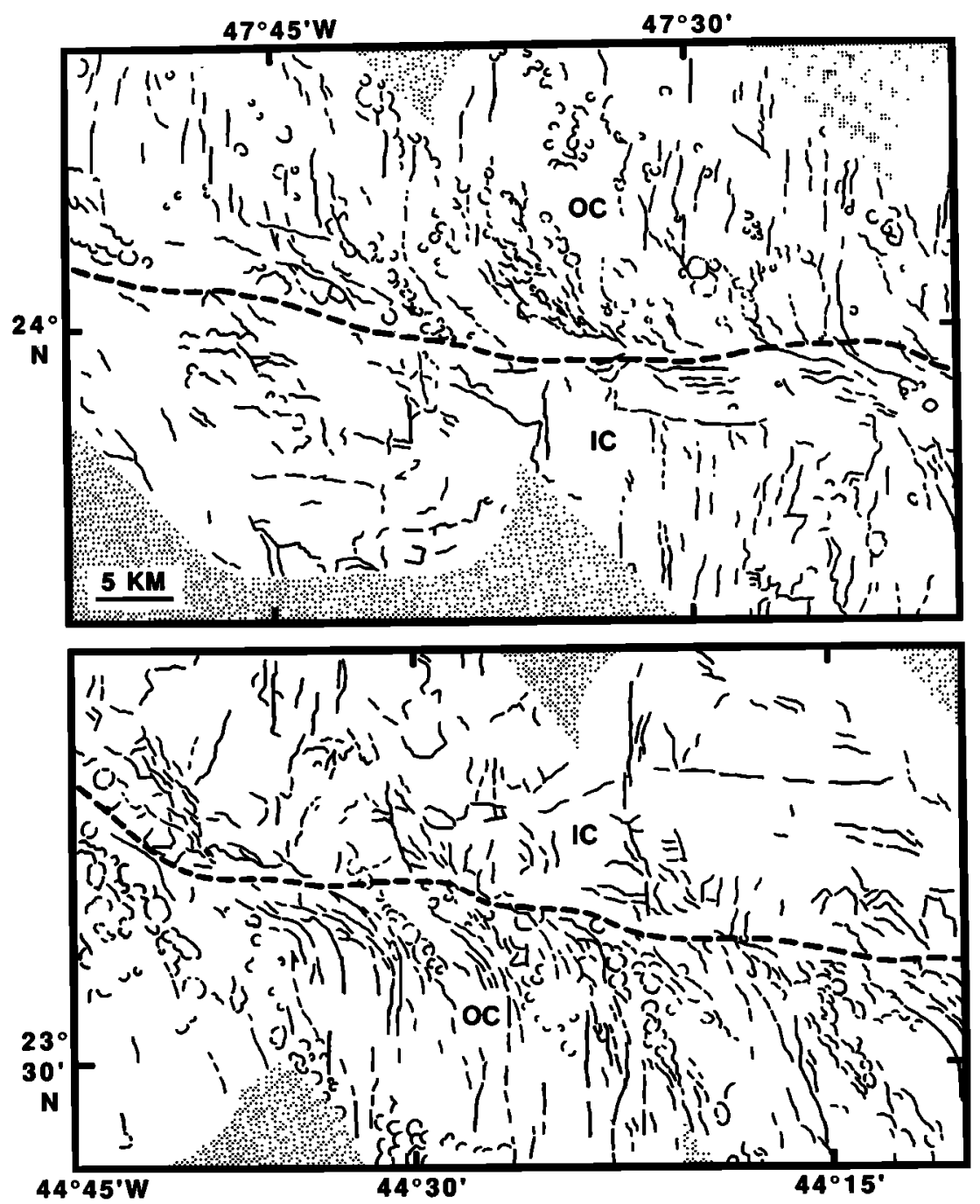

Figure 7. Tracings of faults and volcanic features observed in SeaMARC II side scan sonar images along Kane FZ. Shaded areas have no data. (top) Western limb, -8-12 Ma crust (young, OC side). Axis of fracture valley is indicated by dashed line. OC crust to the north exhibits hummocky volcanic morphology, volcanic cones, and coherently oriented faults that parallel the ridge axis and curve toward the Kane transform. IC crust to the south has few volcanic features and shows more irregular fault patterns. (bottom) Eastern limb, 2-6 Ma crust (young, OC side); $O C$ and IC crust exhibit the same kinds of features as the western limb, but with positions of IC and OC crust reversed. 
of the crests of fault blocks by $5^{\circ}-15^{\circ}$ away from the rift valley is common. In contrast, faults on inside corners occur in two ranges of dip values [Karson and Dick, 1983; 1984]. One suite of faults dips at low to moderate angles $\left(20^{\circ}-60^{\circ}\right)$, with dip directions toward the rift axis and locally toward the ridgetransform intersection or the transform fault zone. These faults are intersected by more steeply dipping $\left(70^{\circ}-90^{\circ}\right)$ faults with throws of a few tens of meters to $150 \mathrm{~m}$ or more. Most of the steep faults dip towand the rift valley, the RTI, or the transform valley, and their orientation often is highly irregular along strike; these faults are developed almost entirely in the subvolcanic crust.

The same kinds of observations appear consistently, but at larger scales, in long-range side scan sonar images and multibeam bathymetric maps of Atlantic Ocean crust (Figure 7 and 8). The slope map in Figure 8 is a useful proxy for understanding fault distribution, with certain limitations. Comparison between faults mapped from submersible dives around the Kane Fracture Zone and multibeam slope maps of the same area suggests that the steeper slopes $\left(230^{\circ}\right)$ are created mostly by sets
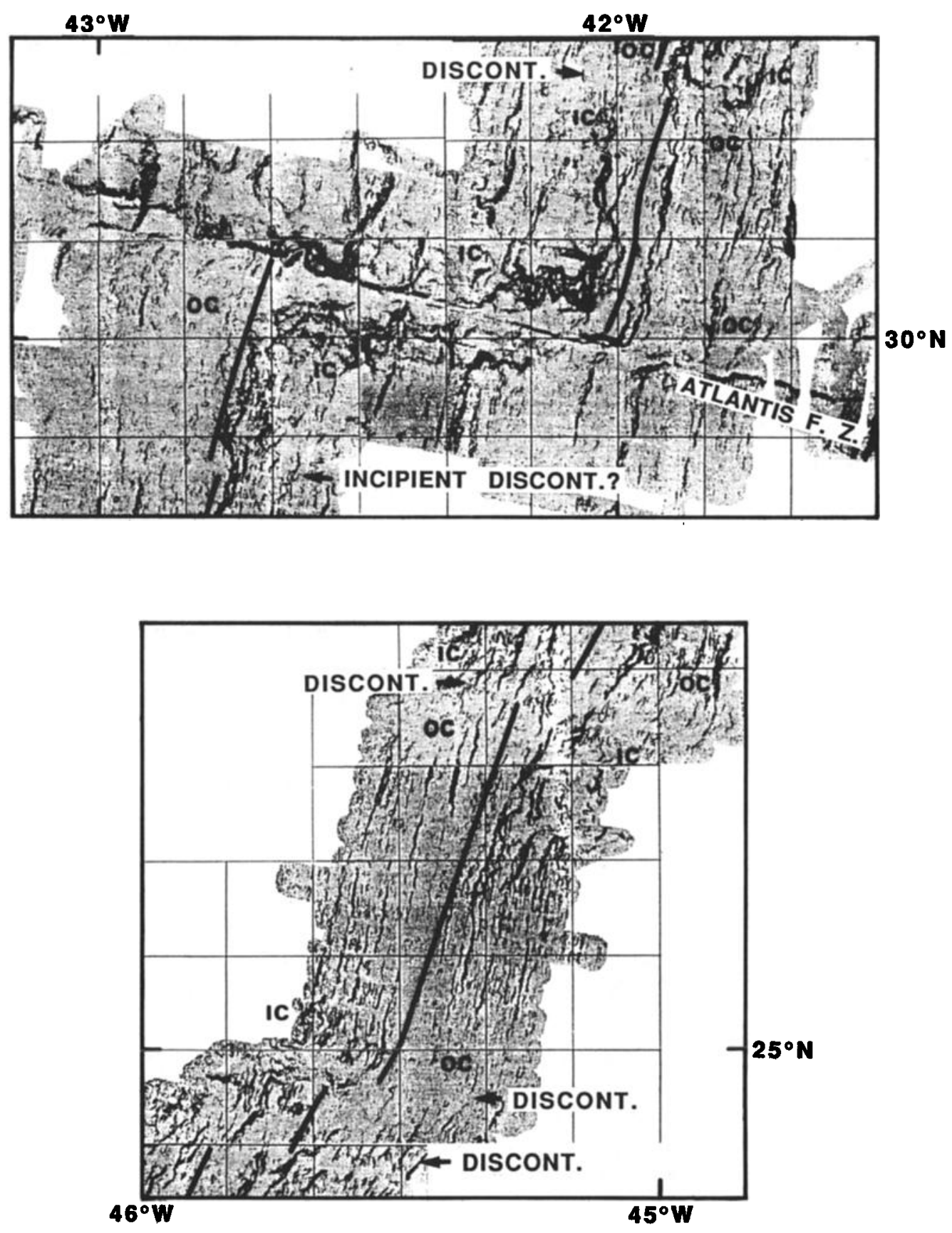

Figure 8. Maps of seafloor slope (top) around the Atlantis FZ and (bottom) at a spreading segment farther south, derived from 200-m gridded Sea Beam bathymetry of Purdy et al. [1990]. Gray-scale intensity is proportional to slope value; steepest slopes (black) are greater than $30^{\circ}$. Bold line marks the axis of the rift valley. Note zones of steep, irregular slope (taken to be an indication of irregular faulting) on IC crust. Finer-scale, linear traces of lesser slopes are interpreted as coherently oriented zones of smaller faults that cross segment centers and outside corners. 
of closely spaced, steep faults and not by individual, lowerangle faults. Furthermore, orientations of individual faults in local, submersible observations often are significantly different from orientations suggested from the slope maps, although average fault orientations are comparable. As might be expected, then, the slope maps filter out details of individual faults, but they provide a relatively accurate depiction of overall fault-zone structure at scales of hundreds of meters or more.

At these scales, the slope maps clearly show significant differences in fault patterns between IC and OC crust (Figure 8). These differences are strongest adjacent to transform discontinuities like those at the Atlantis and Kane Fracture Zones, and they are less obvious but still apparent at second-order discontinuities. OC fault zones have generally lower slope values and narrower widths than fault zones on inside corners. Fault zones on outside corners also strike parallel to the rift axis in long, relatively linear trends, although they often curve in the direction of the ridge axis near the ends of segments (Figure 7 and 8). At inside corners, the average trend of fault zones parallels the rift axis, but secondary orientations parallel some ridge axis discontinuities, particularly at transforms. In addition, IC fault zones commonly exhibit irregular cuspate, arcuate, and convoluted patterns.

The similar fault characteristics observed in fine-scale data (submersible, photographs) and inferred from large-scale data (multibeam slope maps, side scan sonar) indicate that the latter usefully characterize fault patterns in the crust. Furthermore, these fault patterns appear to correlate with the nature of the crust being faulted (volcanic versus subvolcanic [Karson and Dick, 1983]). Thus, to a first order, the fault patterns within spreading ridge segments suggest widespread occurrences of subvolcanic crust at inside corners, in contrast to occurrence of volcanic crust on outside corners. This is consistent with, and extends the results of, the gravity, sampling, and fine-scale morphology studies noted above.

\section{Geological Model of Ridge Segments}

\section{First-Order Considerations}

The observation of low-angle normal-fault surfaces at the eastern inside corner of the Kane FZ, combined with information about exposures of lower crustal and upper mantle rocks at inside corners of other North Atlantic transform faults, led to the hypothesis that extension on the low-angle faults could be responsible for exhuming plutonic and ultramafic rocks [Dick et al., 1981]. Brown and Karson [1988] and Karson [1990] developed this concept, and they noted a strong structural analogy between observations of low-angle normal faulting in slow spreading ocean crust and the development of large-scale detachment faults that expose metamorphic core complexes in the Basin and Range of the western United States [e.g., Wernicke, 1981; Davis and Lister, 1988]. The essence of the oceanic detachment fault model is that $O C$ crust in the rift valley constitutes a hanging wall (above the detachment surface) that is coupled across the adjacent, inactive segment boundary to IC crust in the neighboring segment (Plate 3). IC crust in the rift valley forms the footwall block below the detachment fault, and it has decoupled boundaries at the spreading axis and along the active discontinuity.

To date, development of this hypothesis has been based on limited examples of first-order (transform) discontinuities.
However, all the available data on seafloor morphology, composition, and gravity signature discussed above suggest that there is consistent crustal thinning and exposure of plutonic and ultramafic rocks at inside corners of both first- and secondorder discontinuities. We present here a general model of detachment faulting in slow spreading ocean crust that explains available observations at these discontinuities.

In the proposed model, a low-angle normal (detachment) fault dips below the rift axis from the surface of each inside corner (Plate 3) [Tucholke and Lin, 1992]. Thus, where a ridge segment is bounded by discontinuities with consistent sense of offset, there is cross-rift switch of detachment footwalls and hanging walls over the along-axis length of the segment. Where a segment is bounded by discontinuities of opposite offset (segment C, Figure 1), the entire segment on one side of the rift is an IC footwall block beneath a detachment fault surface, and the opposite side is entirely an $O C$ hanging wall block. The detachment fault dips beneath the intrusive and volcanic carapace that constitutes the neovolcanic zone, and it bottoms out in a zone of distributed shear beneath the brittle/ductile transition. Near a segment center, where melt supply and thermal gradient are thought to be higher than at segment edges [e.g., Fox et al., 1980; Macdonald, 1986], the detachment probably soles out in a shear zone at a shallower subsurface level. In addition, axial seafloor at segment centers tends to be shallower than at segment ends, giving the rift an hourglass shape [Phillips and Fleming, 1977], and rift-mountain seafloor at segment centers usually is deeper than that at inside corners. These topographic effects, together with the shallower brittle/ductile transition, reduce the dip of a detachment fault near a segment center compared to its dip at an adjacent inside corner. Over the along-isochron length of any segment, extension at the inside corner is taken up largely by low-angle detachment faulting, but extension at the outside corner is accommodated only by higher-angle faults. For any segment having consistent sense-of-offset at its bounding discontinuities, the segment center is the location where the IC-to-OC, detachment to no-detachment transition occurs (Plate 3).

As a result of this fault geometry, the basaltic neovolcanic zone forms the hanging wall above the detachment, and it is transported primarily to the outside corner. The IC footwall, stripped of the basaltic crustal carapace, exposes gabbroic lower crust. Toward the segment center, where extension is taken up increasingly by high-angle faults and less by detachment faulting, the stripping mechanism is less effective. Segment centers probably also accrete thicker crust because of increased melt supply [Fox et al., 1980; Macdonald, 1986; Lin et al., 1990]. For these two reasons, crust extending off-axis along the middle of segments should exhibit a fairly thick and complete volcanic section with comparatively few seafloor exposures of lower crustal rocks (Plate 3).

Conceptually the detachment-faulting model has two endmembers. In one, the detachment fault at each inside corner is constantly active and long-lived. As a result, the detachment surface would be continuous over the full inside corner run of a ridge segment. For a spreading segment that has existed from the time of initial continental separation, the breakaway zone for the detachment would be at the continent-ocean boundary in the continental margin. In the other end-member, detachment faulting is an episodic phenomenon and thus may or may 


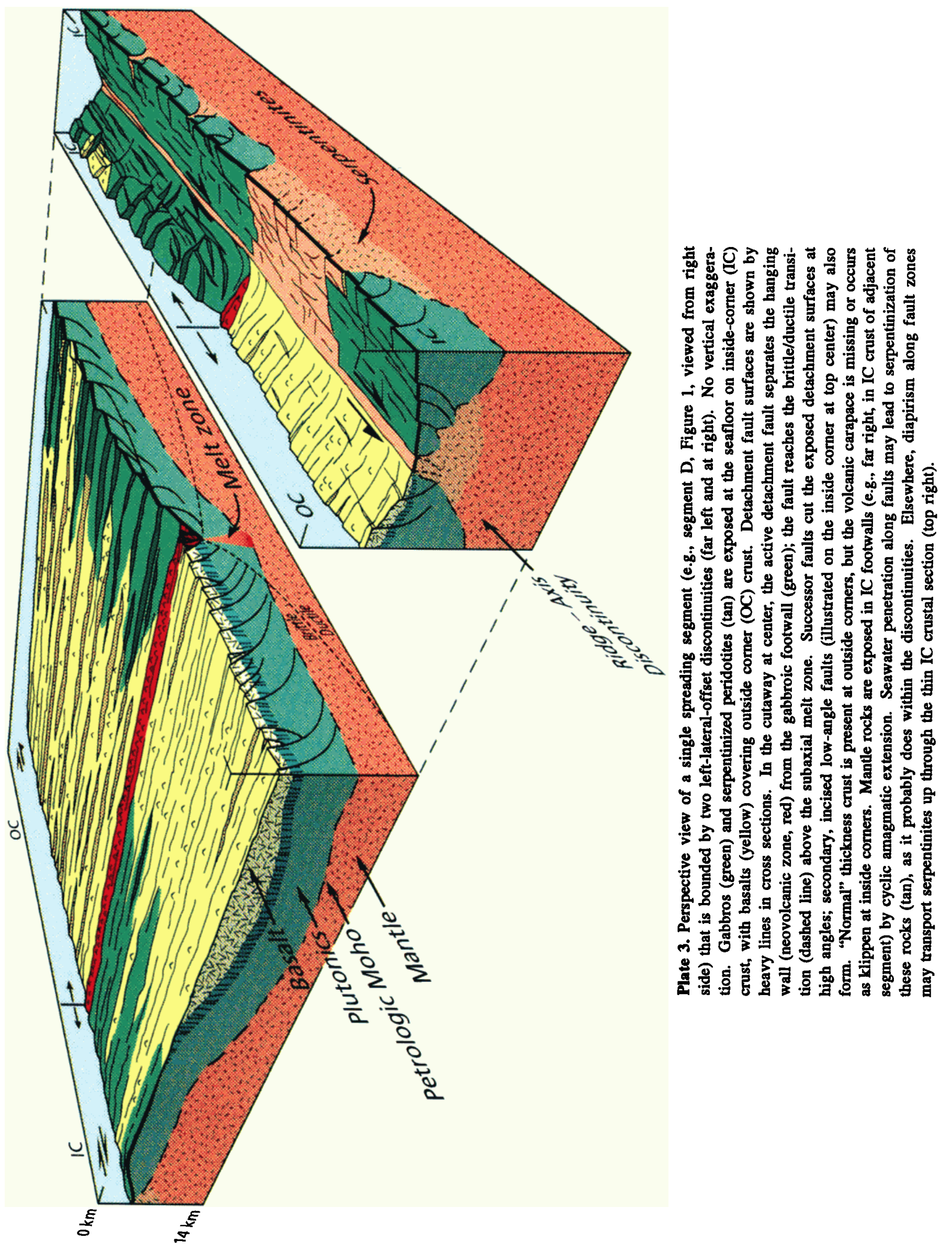


not be currently observed at any given spreading segment [Brown and Karson, 1988; Karson, 1990; Dick et al., 1991]. The existing gravity data suggest that detachment faulting can be relatively continuous. Residual gravity profiles over conjugate IC and OC parts of spreading segments in the TAG survey (Plate 2) show that gravity values are consistently higher over IC crust than over OC crust (Figure 3). This implies that the IC crust is systematically thinner and therefore that the thinning mechanism (detachment faulting) has been continuously operative.

\section{Second-Order Effects}

Two second-order effects modify the detachment model outlined above. First, it is apparent from the common recovery of volcanic rocks on inside comers (Table 1) that stripping of upper crust to the outside corner is an imperfect process. It may not be uncommon for short, high-angle faults in the young hanging wall volcanics to fail more easily than the underlying detachment fault. Volcanic parcels overlying the detachment surface thus could be rafted episodically onto the inside corner as klippen. Such rafting may be most pronounced during periods of peak magmatic activity when newly emplaced volcanics lap farthest onto the detachment footwall. However, because detachment faulting is thought to be a relatively continuous process, we expect that the basaltic carapace will lie unconformably on the detachment surface. The contact may be either tectonic (active faulting between hanging wall and footwall rocks) or depositional (flows on top of the once exposed fault surface).

We interpret the high-angle normal faults $\left(-70^{\circ}-90^{\circ}\right)$ which dissect the original detachment (Plate 3 ) as another secondary effect. These faults are generally colinear with the high-angle faults observed at segment centers and at outside corners; thus they can extend with remarkable continuity across nearly the entire along-isochron length of a segment (Figure 8). The faults are developed primarily in response to uplift of axial crust into the rift valley walls and adjacent rift mountains [e.g., Macdonald, 1986], and they develop significant throws beginning $<0.5 \mathrm{~m} . y$. off-axis. On inside corners these faults curve into the active discontinuities and exhibit orientations oblique or even normal to the adjacent ridge axis; however, the faults appear to have only dip-slip movement which accommodates uplift of IC crust with respect to crust in the discontinuity [OTTER, 1984; Fox and Gallo, 1986].

\section{Cyclicity In Magmatic/Amagmatic Extension}

It is now generally recognized that there is no steady state magma chamber beneath slow spreading ridges and that magmatism must be an intermittent phenomenon [e.g., Detrick et al., 1990]. However, the timescales and relative volumes of melt involved in magmatic phases are poorly understood. On the shortest (smallest) scale, individual basalt flows are separated in time by thousands of years [e.g., Ballard and van Andel, 1977]. At the $100 \mathrm{kyr}$ to $1 \mathrm{~m} . \mathrm{y}$. timescale, Pockalny et al. [1988] have suggested that individual abyssal hills may be formed by magmatic pulses separated by periods of extension. This sub-million-year alternation between phases of essentially amagmatic or weakly magmatic extension and phases of magmatically robust extension has also been suggested to explain the variable exposure of basaltic, plutonic, and ultramafic rocks on the walls of rift valleys [e.g., Cannat, 1993]. Such cyclicity will have a profound effect on the structure and composition of the ocean crust along the run of spreading segments.
Residual gravity anomalies (Plate $2 b$ ) show significant variability within the bands of gravity highs and lows that extend off-axis along IC and OC crust, respectively. This variability appears as closed relative highs and lows. It ranges from 5 to $15 \mathrm{mGal}$ (rarely $20 \mathrm{mGal}$ ) over IC crust and slightly less (typically $\sim 10 \mathrm{mGal}$ ) over OC crust in the TAG gravity data. The variation is quasi-periodic, with wavelengths of the order of $2.0 \pm 0.4 \mathrm{~m}$.y. [Tucholke and Lin, 1992]. Longer off-axis gravity records, out to $-28 \mathrm{Ma}$, show similar wavelengths but also suggest additional, longer-wavelength variability with periods up to $-9 \mathrm{~m} . \mathrm{y}$. [Lin et al., 1993]. We interpret this variability to represent changes in crustal thickness and density. Assuming standard crustal densities of $2.7 \mathrm{Mg} \mathrm{m}^{-3}$, the amplitudes of thickness variations are up to about $2 \mathrm{~km}$ in IC crust and typically about $1 \mathrm{~km}$ in OC crust. The primary mechanism controlling this thickness variation is thought to be cyclicity of magmatic and amagmatic extension, superimposed on detachment faulting.

A schematic evolution of detachment faulting over a full magmatic/amagmatic cycle is illustrated in Figure 9 for an IC/OC pair. In Figure 9a the spreading segment is in a magmatic phase. A magma body may or may not be present in the position of this cross section near the segment edge, but the thermal budget of the segment is high, the brittle/ductile transition is relatively elevated beneath the spreading axis, and the detachment fault soles out at a shallow level. Volcanic rocks of the neovolcanic zone are deposited unconformably on the detachment surface; they are extended in synthetic and antithetic faults, and part of this hanging wall may subsequently be rafted as klippen onto the inside corner.

Figure $9 \mathrm{~b}$ represents the early part of amagmatic or weakly magmatic extension following the magmatic phase. As the crust cools and isotherms are depressed, the detachment fault extends through the crust following a shear zone beneath the brittle/ductile transition. The toe of the fault probably will dip significantly, following the steepest thermal gradient beneath the spreading axis. Thus within a relatively short time, deep-crustal rocks are exhumed in the IC footwall. As amagmatic extension continues (Figure 9c), ultramafic rocks become widely uplifted and exposed on the inside corner. Late in the amagmatic phase, crust in the $O C$ hanging wall also becomes highly extended. Faults there may provide deep pathways for seawater penetration into the upper mantle, facilitating serpentinization and serpentinite diapirism which can carry ultramafic rocks and allochthonous lower crustal rocks to the seafloor [e.g., Bonatti, 1976; Francis, 1981]. Serpentinization of the footwall mantle (not shown in Figure 9) probably also occurs, but it may be less intense because the footwall is not as strongly extended and faulted.

At the beginning of a new magmatic phase (Figure 9d), the thermal budget increases, the brittle/ductile transition rises, and the detachment fault again soles out at a shallow level. Generation of a lower crustal gabbroic section may recommence, with a normal crustal section being developed at the outside corner.

\section{Discussion}

\section{Structure and Stratigraphy of Inside Corner Crust}

The detachment model, and the cyclicity of magmatic versus amagmatic extension, have important implications for the structure and stratigraphy of inside corner crust on slow spreading ridges. During a phase of magmatic extension the 
OUTSIDE CORNER

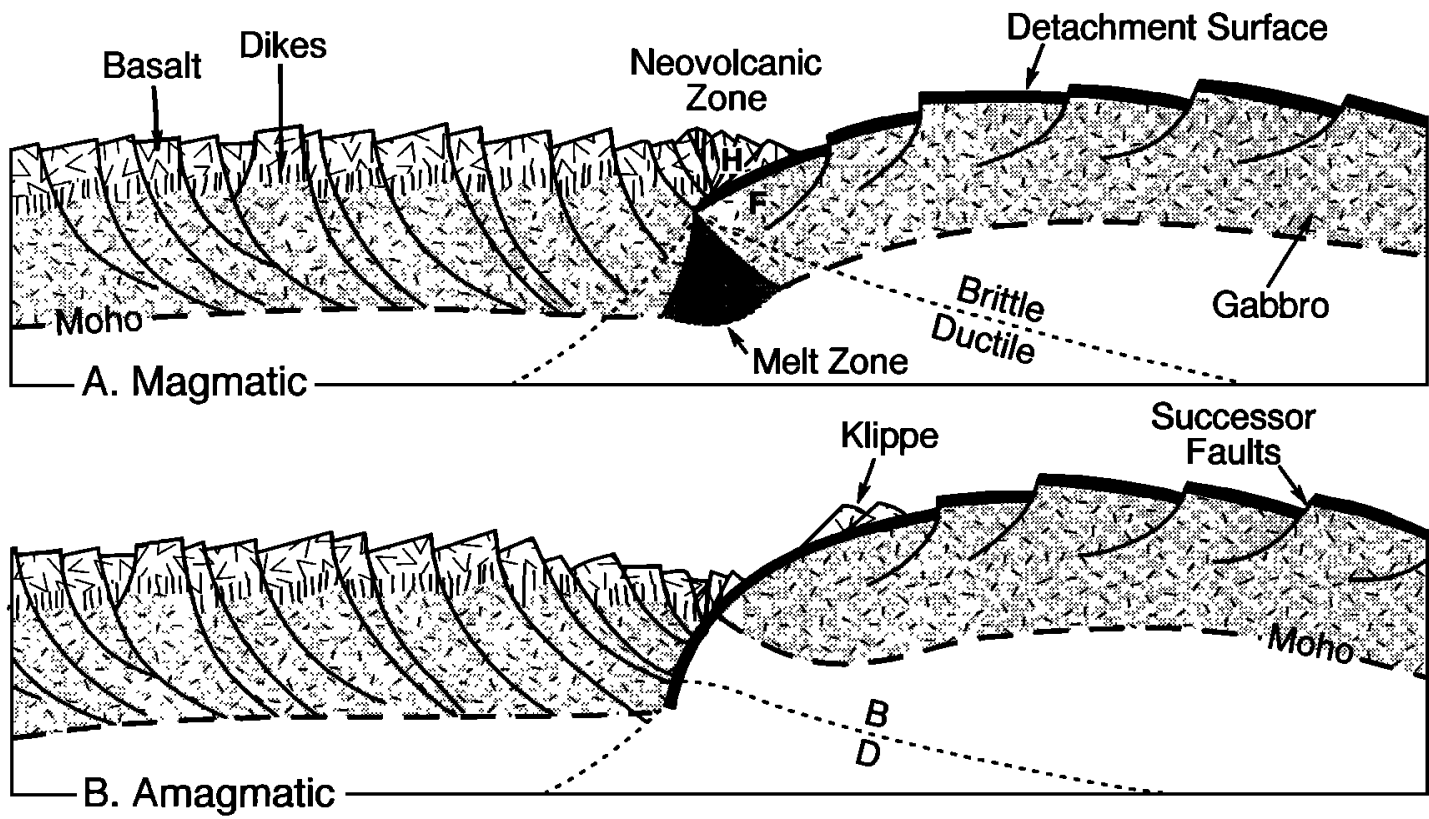

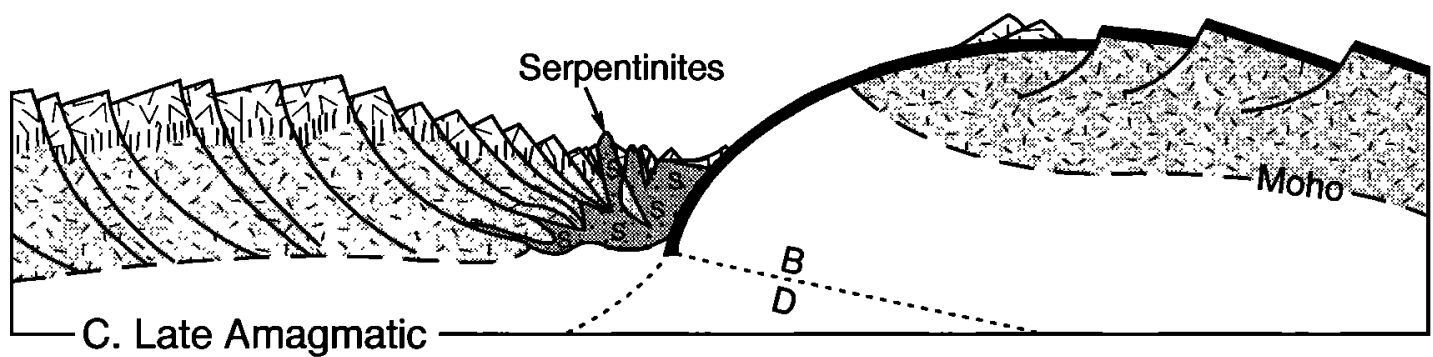

C. Late Amagmatic

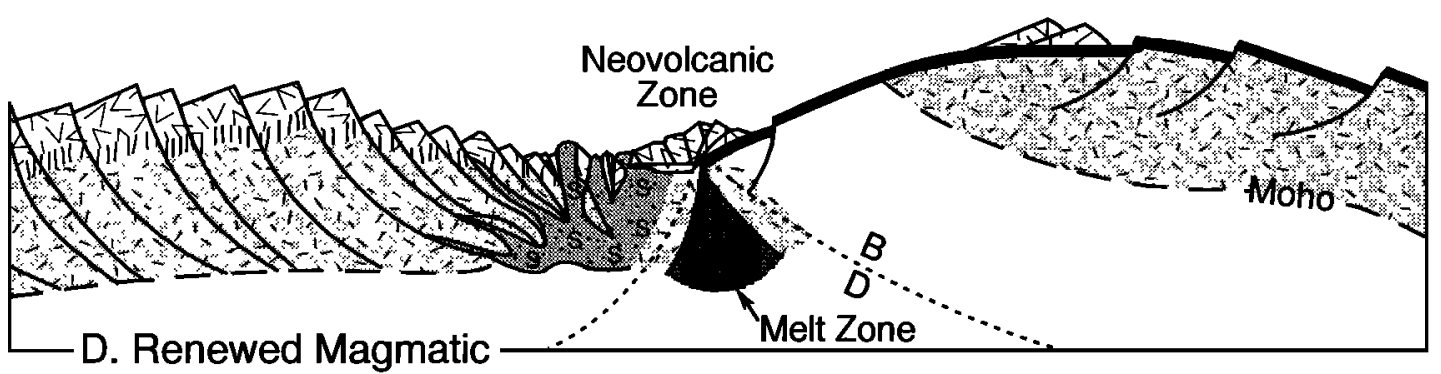

Figure 9. Cross section across rift axis through an inside/outside corner pair, showing schematic evolution of a detachment fault through a cycle of magmatic/amagmatic extension. Section extends to crest of rift mountains $\sim 2 \mathrm{~m}$.y. to either side of rift axis. $\mathrm{H}$ is hanging wall above detachment fault, and $\mathrm{F}$ is footwall. See text for discussion.

detachment fault presumably soles out near the top of gabbroic crust that is forming around the perimeter of the subaxial melt zone. It also generally underlies sheeted dikes (and the overlying volcanics), to the extent that the dikes are formed by intrusion of basaltic melts into brittle upper crust. This is consistent with sample recoveries (Table 1) which suggest that diabase dikes are relatively uncommon on IC crust (40 occurrences in 358 recoveries, or 11\%). Thus the normal IC crustal section generated during magmatic extension ideally consists of gabbroic rocks that immediately underlie the detachment surface.

As magmatic extension wanes and the detachment dives into the lithosphere, successively deeper lithofacies become exposed in the footwall (e.g., cumulate ultramafics followed by residual ultramafics of the upper mantle). These rocks should exhibit a wide variety of compositions (dunites, lherzolites, etc.) and structures (e.g., mylonites, cataclasites) that represent all the complexities of subaxial anatexis and deformation.

An attractive feature of the diving-detachment concept is that only a short period of time is required for the fault to reach and exhume upper mantle rocks. The dip angle of the toe of the detachment fault during these episodes is unknown. With extreme (vertical) dip, deep structural levels could rise in the footwall at a rate equal to the spreading half rate $(-10$ to 17 $\mathrm{km} / \mathrm{m}$.y. in the Atlantic). This value would be reduced to about 7 to $12 \mathrm{~km} / \mathrm{m}$.y. for a dip of $45^{\circ}$. Even at such reduced angles, significant exposure of upper mantle rocks could occur in 0.3- 
$0.6 \mathrm{~m} . y$. , assuming an average IC crustal thickness of $4 \mathrm{~km}$. An important implication of a steeply dipping detachment toe is that originally horizontal lower crustal and upper mantle structures, where preserved during exhumation along the detachment, will be rotated toward the vertical as the footwall is exposed; these structures should intersect the detachment surface at high angles. Detailed near-bottom studies of lower crustal and upper mantle exposures on inside-corner crust can test these postulated relations.

The footwall exhumation described above is consistent with the deformation history that is commonly observed for ultramafic tectonites in the slow spreading Atlantic and Indian Oceans [e.g., Aumento and Loubat, 1971; Bassias and Triboulet, 1992; Cannat et al., 1992]. These rocks typically have an initial history of low-stress, high-temperature plastic deformation that probably occurred at depths of $10 \mathrm{~km}$ or more in the mantle. They subsequently record hydration (e.g., amphibolization, serpentinization) and cataclasis, mylonitization, or shearing under progressively lower-temperature, higher-stress conditions. We attribute this later history to shoaling, cooling, and deformation of the IC footwall. Seawater penetrating the rocks through fractures and faults appears to be the primary source of water for the hydration reactions that form serpentinites [Bonati et al., 1984].

In a succeeding phase of magmatic extension, the exhumed lower crustal or upper mantle rocks in the rift axis should be intruded by gabbros and basaltic melts. Ultramafic rocks cut by gabbroic dikelets have been recovered from slow spreading crust in both the Atlantic and Indian Oceans [Mevel et al., 1991; Cannat et al., 1992; Fisher et al., 1986], and they may be examples of such intrusive relations. If rejuvenated magmatism is so robust that a magma chamber forms, gabbros may replace and unconformably underlie upper mantle footwall rocks (Figure 9d).

\section{Structure and Stratigraphy of Outside Corner Crust}

During phases of magmatic extension, $O C$ crust develops a "normal" crustal sequence consisting (from bottom to top) of cumulate ultramafics, gabbros, sheeted diabase dikes, and pillow basalts. We suggest that during phases of amagmatic extension this section is thinned in two ways (Figure 9). One is extension taken up by high-angle $O C$ faults. Movement on these faults is unlikely to thin the crust significantly or to cause much exposure of deep crustal levels, except perhaps late in a long phase of amagmatic extension. Second, the crust will be effectively thinned and intruded by serpentinite diapirs.

Thinning by these mechanisms should result in OC seafloor outcrops primarily of volcanic rocks, with local occurrences of serpentinized ultramafics. This is essentially what we observe in sampling results on outside corners (Table 1). Plutonic rocks and diabases have rarely been recovered, and we infer that they are only infrequently exposed on steep fault scarps or carried to the surface as allochthonous blocks by serpentinite diapirism. Serpentinized ultramafic rocks, although uncommon, have been sampled more frequently on $O C$ crust, and there are some well documented $O C$ areas where such rocks are widely exposed. One is in the MARK area at $23^{\circ} 20^{\prime} \mathrm{N}$ (Figure 5). Others occur at the outside corners of the Fifteen-Twenty Fracture Zone [Casey et al., 1992; $H$. Dick et al., unpublished manuscript, 1990]. Our model suggests that these rocks have been emplaced primarily by serpentinite diapirism, late within a phase of amagmatic extension. It is possible that under such conditions, low-angle faults may develop above shallow shear zones within the serpentinites. With renewed magmatism, OC crust could develop a complex record of serpentinites which are intruded by dikes [e.g., Mevel et al., 1991] and unconformably capped by volcanics.

\section{High-Angle Faults}

The long, relatively linear faults that often extend over the along-isochron length of spreading segments (Figure 8) appear to form during uplift of rift valley crust into the bordering rift mountains. Most of these faults are steeply dipping $\left(70^{\circ}\right.$ $90^{\circ}$ ) at the seafloor, and on inside corners they are interpreted as successor faults that dissect the detachment surface. Dips of the high-angle faults at depth are uncertain. The fault blocks typically are rotated, as indicated by backtilting of block crests by $5^{\circ}-15^{\circ}$, and this rotation must be accomplished by flattening of the zone of failure at depth. Both listric faults (curvilinear, concave-upward) and planar faults which intersect a deep, more level zone of shear deformation, meet this criterion. Seismic reflection profiles oriented along plate flow lines over Cretaceous Atlantic crust show apparent fault surfaces of both listric and planar aspect which dip toward the ridge axis [e.g., White et al., 1990; Morris et al., 1993]. Both kinds of faults commonly sole out in banded, subhorizontal zones of high reflectivity in the lower crust or upper mantle. These basal zones have been variously interpreted as sills or variations in fluid content [White et al., 1990], as relic magma chambers [Mutter et al., 1985], or as zones of deformation at the bases of fault blocks [Mutter and Karson, 1992]. Whatever their origin, they must have accommodated some shear strain if the intersecting, dipping reflections are indeed faults.

We assume that the crustal faults sole out just beneath the brittle/ductile transition. The depth of this transition is controlled by the thermal state of the crust [e.g., Chen and Morgan, 1990], and it consequently will vary with position in a spreading segment. Two factors suggest that isotherms, and therefore the depth of the brittle/ductile transition, may be elevated at inside corners compared to outside corners: (1) Because of thermal edge effects, isotherms are skewed where they cross ridge axis discontinuities, and IC crust is warmer than OC crust [Phipps Morgan and Forsyth, 1988; Lin and Phipps Morgan, 1992; Sparks et al., 1993]. (2) Detachment faulting exhumes deep, warm lithosphere at inside corners. In addition, significant asymmetries may exist in hydrothermal circulation through IC and $\mathrm{OC}$ crust. If, for example, the upper crustal volcanics and sheeted dikes of outside corners are more highly fractured, faulted, and fissured and thus more permeable than the plutonic/ultramafic rocks at inside corners, then cooling of $\mathrm{OC}$ crust by hydrothermal circulation would be enhanced. Unfortunately, little is known about the bulk permeability of $\mathrm{OC}$ and IC crust, so the effects of hydrothermal circulation currently are unresolved.

Elevation of the brittle/ductile transition beneath inside corners also may be enhanced by the occurrence of serpentinites. Faults penetrating the thinned IC crust provide potential pathways for seawater to reach the upper mantle and to form serpentinites in hydration reactions. Geologically rapid serpentinization under these conditions occurs at temperatures from about $100^{\circ}$ to $500^{\circ} \mathrm{C}$ [O'Hara, 1967; Macdonald and Fyfe, 1985]. Serpentinization could facilitate development of weak, shallow zones of shear strain that take up the motion of normal faults in the overlying brittle crust. 

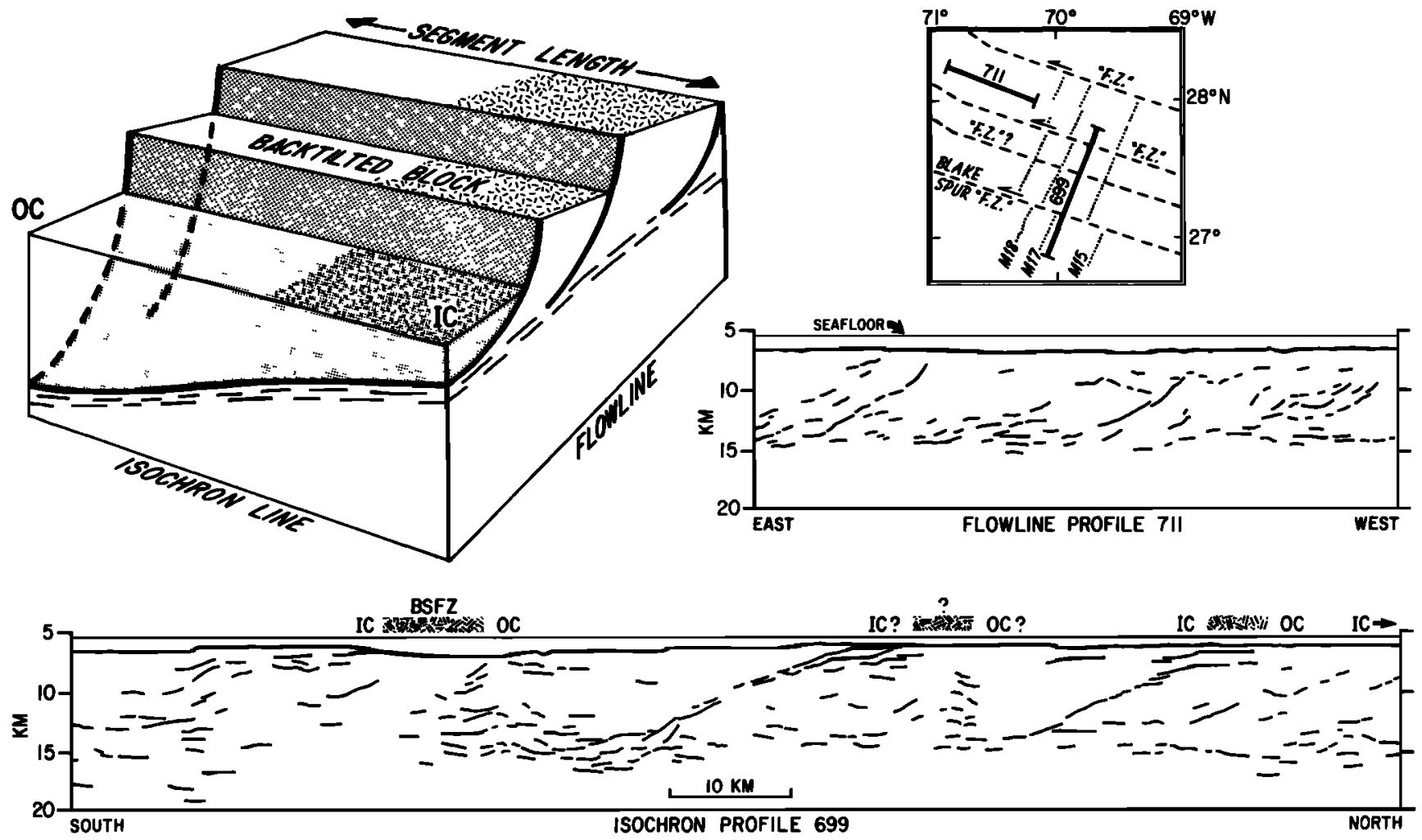

Figure 10. Block diagram (top left, looking away from rift axis) showing possible configuration of highangle faults that extend over the full along-isochron length of a single spreading segment; at inside corners these faults dissect the detachment surface (tick pattern). The faults sole out at shallow levels on inside corners and near the base of full thickness crust at outside corners. Fault surfaces dip from IC to OC along isochron lines, and along flow lines they dip toward the ridge axis. Compare with similar geometry of apparent faults in multichannel seismic reflection profiles over Cretaceous crust in the western North Atlantic (bottom and right, traced from profiles by White et al. [1990]). On isochron profile 699, the positions of inside and outside corners are labeled, based on offsets in $M$ series magnetic anomalies mapped by Minshull et al. [1991](inset). The questioned segment boundary is inferred on the basis of seismic structure and has no apparent offset in magnetic anomalies; it may be a zero-offset discontinuity [Schouten and White, 1980]. BSFZ is Blake Spur Fracture Zone. In flow line profile 711, note that faults usually are not imaged in the upper crust.

From all these considerations, we infer that the brittle/ductile transition at inside corners is elevated relative to that at outside corners. Outside corner crust probably has relatively normal thickness, with the brittle/ductile transition in the lower crust [Chen and Morgan, 1990]. Thus, over the along-isochron length of a spreading segment the brittle/ductile transition will deepen from inside corner to outside corner.

A suite of high-angle faults which fit this pattern and which flatten with approach to the brittle/ductile transition is illustrated schematically in Figure 10. Imaged along an isochron line, the faults dip gently from shallow levels at the inside corner to near the base of the crust at the outside corner. Imaged across isochrons, the faults dip somewhat more steeply toward the ridge axis. This picture is in general agreement with dip direction, dip magnitude, and lateral extent of apparent faults in seismic reflection profiles across Cretaceous crust in the western North Atlantic (Figure 10). In isochron-parallel profiles the faults dip at about $20^{\circ}$ toward OC crust, and together with their apparent basal shear zones, they extend over nearly the full lengths of segments. Faults facing the ridge axis have a steeper average dip where they are imaged in the central and lower crust $\left(20^{\circ}-40^{\circ}\right.$ [Morris et al., 1993]), and they typically can be traced for 10 or $12 \mathrm{~km}$. These faults normally are not imaged in the upper part of the crust, possibly because of steep dips, distributed deformation in heterogeneous rocks, or masking by hydrothermal alteration [White et al., 1990].

Mutter and Karson [1992] proposed a different scenario for fault patterns within a slow spreading segment. They envisioned oppositely dipping detachment faults (across-rift) much as we described above, but with the detachments connected through arcuate faulting which defines an accommodation zone and creates oblique structures at the segment center. In their geometry the detachment surfaces have alongisochron dips from segment centers toward inside corners, together with complex strain in the central accommodation zone. This geometry is difficult to reconcile with dips of along-isochron faults toward outside corners (Figure 10, bottom) and with the commonly observed continuity and linearity of fault zones that pass segment centers in rift valley walls (Figure 8).

It is possible that some of the high-angle successor faults on inside corners may develop into low-angle faults akin to detachment faults (Plate 3). Their development could be facilitated by the presence of relatively shallow serpentinites, and 
their intermittency of occurrence would be similar to that illustrated by Brown and Karson [1988], Karson [1990], and Dick et al. [1991]. This process of incisement would transfer rocks that were formerly in the footwall of the main detachment into the hanging wall of the new fault [Davis and Lister, 1988]. Strictly speaking, it may not be appropriate to call these features detachment faults, since they are of limited extent and have small translational displacements [cf. Davis and Lister, 1988]. In our model, these incised low-angle faults are considered to be subsidiary to the master detachment as a mechanism for exposing lower crustal and upper mantle rocks at inside corners.

At both inside and outside comers, high-angle faults tend to curve near ridge-axis discontinuities (Figures 7 and 8). This curvature is thought to reflect rotation of the direction of maximum tensile stress at the offsets [e.g., Searle and Laughton, 1977; Fox and Gallo, 1984]. However, significant additional irregularity of fault patterns is observed on IC crust. This irregularity may be a consequence of differences in IC versus $O C$ composition. Inside corner lithosphere is an aggregate of variably deformed and intruded lower crustal and upper mantle rocks, and patterns of failure in this medium probably will be complex. Crust at segment centers and outside corners, in contrast, is thought to bave more uniform composition, and its failure in relatively coherent fault patterns may reflect this greater uniformity.

\section{Relation of Structure to Spreading Rate}

The occurrence of detachment faulting and the cyclicity of magmatic/amagmatic crustal accretion must vary with rate of seafloor spreading; the primary indicators of crustal thinning (plutonic/ultramafic exposures, gravity banding, morphological variations) observed in slow spreading crust in the Atlantic and Indian Oceans are strongly subdued or wholly absent on fast spreading ridges such as those in the Pacific [e.g., Fox and Gallo, 1989; Madsen et al., 1990]. To a first order, we infer that detachment faulting is restricted to slower spreading ridges where a rift valley is developed; this is suggested by the correlation between rift valley depth and the degree of asymmetry in IC/OC crustal elevations, which would appear to be linked to the detachment process (Figure 2 [Severinghaus and Macdonald, 1988]). Rift valleys normally are present on midocean ridges having full spreading rates less than about 25-30 $\mathrm{mm} / \mathrm{yr}$ and are absent at rates above about $40 \mathrm{~mm} / \mathrm{yr}$ [Macdonald, 1986]. At rates in the $25-40 \mathrm{~mm} / \mathrm{yr}$ range, the development of detachments may be intermittent, perhaps varying inversely with the intensity and duration of phases of magmatic extension. In such cases, detachment faulting could be very similar in character to the models proposed by Karson [1990] and Dick et al. [1991]. The limited development of IC/OC differences in relative crustal thickness in the South Atlantic (spreading rate $33 \mathrm{~mm} / \mathrm{yr}$ [Kuo and Forsyth, 1988]) could be the expression of such intermittency. At slower spreading rates, the prevalence of long-lived master detachments is expected to increase, and banded, flow line patterns of crustal thickness variation should be developed more consistently.

\section{Conclusions}

Data from a wide variety of sources, including multibeam bathymetry, side scan sonar, crustal sampling, and gravity field, indicate that there are fundamental structural and compo- sitional differences between the crustal sections at inside and outside corners of ridge segments in slow spreading ocean crust. These differences exist at both first-order (transform) and second-order (nontransform) discontinuities. Crust at inside corners appears to be tectonically thinned, and it consists of a complex of lower crustal and upper mantle rocks that is capped by a thin and intermittent carapace of basaltic intrusive and volcanic rocks. On average, $O C$ crust probably has a more normal thickness $(\sim 6 \mathrm{~km})$ and a relatively complete crustal stratigraphy. The character of crustal faulting and the development or lack of volcanic morphology are quite sensitive to IC or OC tectonic setting; these characteristics therefore can be useful for interpreting sense of offset in ridge flank crust where classical indicators such as magnetic anomalies may be ambiguous.

We have outlined a model of low-angle, normal detachment faulting wherein inside corners comprise footwalls and outside corners represent hanging walls. Available gravity data, which show footwall crust to be consistently thinner than hanging wall crust, suggest that the detachment faulting is a continuous or nearly continuous process in slow spreading crust $(<-25-30 \mathrm{~mm} / \mathrm{yr}$ full rate). In these environments the basaltic carapace on IC crust, where present, is expected to occur as klippen in tectonic or depositional contact with an underlying detachment surface. At faster spreading rates of 25$40 \mathrm{~mm} / \mathrm{yr}$, but where a rift valley is still developed, the detachment process may become intermittent, with inside corners locally exhibiting a complete crustal section and no detachment faulting. We suggest that detachment faulting is unlikely to occur in crust spreading at rates greater than $\mathbf{4 0}$ $\mathrm{mm} / \mathrm{yr}$ where no rift valley is present.

The master detachment faults at inside corners are incised by high-angle successor faults that are created by uplift of rift valley crust into the bordering rift mountains. The locations and orientations of these faults are controlled both by the local stress fields along the rift axes and at the ridge-discontinuity intersections and by variable lithospheric composition created by cyclicity in crustal accretion. Consequently, the structure and igneous stratigraphy of inside corners is expected to be complex. The high-angle successor faults at times may also develop into local, low-angle normal faults above a shallow brittle/ductile transition at inside corners. This incisement, as well as possible subsequent excisement (transfer of hanging wall rocks to the footwall of a new detachment [Davis and Lister, 1988]), will further complicate the structural framework.

The high-angle faults associated with uplift into the rift valley walls commonly extend linearly and quasi-continuously over the complete along-isochron lengths of spreading segments. The faults most likely have decreasing dips with depth in the crust and sole out in a zone of shear deformation just below the brittle/ductile transition; this zone may be relatively shallow beneath inside corners but it deepens to near the base of normal-thickness crust beneath outside corners. We suggest that it is these faults, and not the master detachment faults, which have been imaged by reflection profiling in Cretaceous crust of the western North Atlantic Ocean.

Cycles of magmatic/amagmatic extension strongly modulate the composition, thickness, and structural framework of both IC and $O C$ crust. Available residual gravity data over both inside and outside corners suggest that a full cycle of magmatic/amagmatic extension may average about $2 \mathrm{~m} . \mathrm{y}$. in duration but that longer- and shorter-period variations also 
may exist. During phases of magmatic extension, the IC footwall of the master detachment exposes largely gabbroic lower crustal rocks that are intermittently capped by basalt. It is during these magmatic phases that the $O C$ hanging wall will most closely approximate a normal crustal section having standard igneous stratigraphy and velocity structure.

As a spreading segment enters a phase of amagmatic extension, the crust at the spreading axis cools, the brittle/ductile transition deepens into the upper mantle, and the toe of the detachment dives to follow: With continued amagmatic extension, footwall uplift rapidly exhumes progressively deeper rocks from the lithosphere. In addition, through-crust faults in the hanging wall facilitate seawater penetration and serpentinization of the upper mantle, and this may eventually stimulate serpentinite diapirism in the hanging wall. The longer the period of amagmatic extension, the more pronounced will be the effective thinning of the hanging wall by faulting and serpentinite diapirism, and the greater will be the possibility of OC exposure of upper mantle rocks. From these considerations, we infer that variability in crustal thickness and composition will be greatest in IC crust and will be complementary but less well developed in OC crust.

The long-term operation of detachment faulting at the ridge axis results in creation of ribbons of thin crust that extend offaxis along the old, IC sides of first- and second-order discontinuitles, together with ribbons of more normal crust at segment centers and along young, $O C$ sides of the discontinuities [Tucholke and Lin, 1991]. Thus significant along-isochron variability in crustal composition, extending well beyond the bounds of known anomalous crust within discontinuities, should exist in old ocean crust along the flanks of slow spreading mid-ocean ridges. Optimal operation of the detachment process could result in up to half of the ocean crust exhibiting thinned or missing gabbroic or volcanic sections. Ophiolites in the French Western Alps and the Apennines commonly display these features [Lagabrielle and Cannat, 1990; Tricart and Lemoine, 1991], and it therefore is possible that the Ligurian ocean crust from which the ophiolites were derived was accreted at slow spreading rates $(<25 \mathrm{~mm} / \mathrm{yr})$. If so, these ophiolites are a potentially rich source of information about the structure and stratigraphy of ocean crust affected by detachment faulting.

In the ocean basins, two kinds of fundamental studies are needed to assess the patterns of crustal heterogeneity, both across and along isochrons, that are suggested by the detachment model. First, long (20-30 m.y.) records of conjugate IC and $O \dot{C}$ crust must be examined with detailed morphological and potential-field surveys on the two flanks of a slow spreading ridge. These surveys can examine the degree of variability in crustal composition and relative crustal thickness and can determine whether these factors vary sympathetically at inside and outside corners. Second, refraction seismic studies are needed to test the validity of crustal thickness patterns suggested by the geological and geophysical data. However, serpentinization is likely to have altered upper mantle and deepest crustal ultramafic rocks, and it will strongly affect seismic velocity structure. This difficulty can best be overcome by carefully siting the seismic experiments within the context of detailed geophysical surveys and by analysis of crustal thickness patterns using combined modeling of seismic and gravity data. Fine-scale, near-bottom geological mapping and sampling will provide the ultimate tests of the observations and predictions made from these large-scale data.
Acknowledgments. This research was supported by Office of Naval Research grants N00014-90-J-1621 and N00014-91-J-1433 and by National Science Foundation grants OCE 8716713 and OCE 9020408. We thank H.J.B. Dick, G. Hirth, J. Karson, and M. Kleinrock for helpful discussions and $G$. Hirth and $R$. Pockalny for thoughtful reviews of the manuscript. Contribution 8369 of Woods Hole Oceanographic Institution.

\section{References}

Ambos, E. L., and D. M. Hussong, Oceanographer transform fault structure compared to that of surrounding oceanic crust: Results from seismic refraction data analysis, J. Geodym., 5, 79-102, 1986.

Aumento, F., and H. Loubat, The Mid-Atlantic Ridge near $45^{\circ} \mathrm{N}$, XVI, Serpentinized ultramafic intrusions, Can. J. Earth Sci., 8, 631-663, 1971.

Ballard, R. D., and T. H. vin Andel, Morphology and tectonics of the inner rift valley at lat. $36^{\circ} 50^{\prime} \mathrm{N}$ on the Mid-Atlantic Ridge, Geol. Soc. Am. Bull., 88, 507-530, 1977.

Bassias, Y., and C. Triboulet, Petrology and P-T-t evolution of the South West Indian Ridge peridotites. A case study: East of the Melville Fracture Zone at $62^{\circ} \mathrm{E}$, Lithos, 28, 1-19, 1992.

Bercovici, D., H. J. B. Dick, and T. P. Wagner, Nonlinear viscoelasticity and the formation of transverse ridges, J. Geophys. Res., 97, 14,19514,206, 1992.

Blackman, D. K., and D. W. Forsyth, Isostatic compensation of tectonic features of the Mid-Atlantic Ridge: $25^{\circ}-27^{\circ} 30^{\prime} \mathrm{S}, J$. Geophys. Res., 96, 11,741-11,758, 1991.

Boillot, G., D. Mougenot, J. Girardeau, and E. L. Winterer, Rifting processes on the west Galicia margin, Spain, in Extensional Tectonics and Stratigraphy of the North Atlantic Margins, edited by A. J. Tankard and H. R. Balkwill, AAPG Mem., 46, 363-377, 1989.

Bonatti, E., Ultramafic rocks from the Mid-Atlantic Ridge, Nature, 219, 363-364, 1968

Bonatti, E., Serpentinite protrusions in the oceanic crust, Earth Planet. Sci. Lett., 32, 107-113, 1976.

Bonatti, E., J. R. Lawrence, and N. Morandi, Serpentinization of oceanic peridotites: Temperature dependence of mineralogy and boron content, Earth Planet. Sci. Lett., 70, 88-94, 1984.

Brown, J. R., and J. A. Karson, Variations in axial processes on the MidAtlantic Ridge: The median valley of the MARK area, Mar. Geophys. Res., 10, 109-138, 1988.

Cannat, M., Emplacement of mantle rocks in the seafloor at mid-ocean ridges, J. Geophys. Res., 98, 4163-4172, 1993.

Cannat, M., D. Bideau, and H. Bougault, Serpentinized peridotites and gabbros in the Mid-Atlantic Ridge axial valley at $15^{\circ} 37^{\prime} \mathrm{N}$ and 1652N, Earth Planet. Sci. Lett., 109, 87-106, 1992.

Casey, J. F., M. Cannat, and FARANAUT Scientific Party, Crustal architecture and mechanisms of ultramafic and gabbroic exposure along rift valley walls of the Mid-Allantic Ridge north and south of the $15^{\circ} 20^{\circ}$ transform (abstract), Eos Trans. AGU, 73 (43), Fall Meeting Suppl., 537, 1992.

Chen, Y., and W. J. Morgan, A nonlinear theology model for mid-ocean ridge axis topography, J. Geophys. Res., 95, 17,583-17,604, 1990.

Collette, B. J., Fracture zones in the North Atlantic: Morphology and a model, J. Geol. Soc. London, 143, 763-774, 1986.

Cormier, M. H., R. S. Detrick, and G. M. Purdy, Anomalously thin crust in oceanic fracture zones: New seismic constraints from the Kane Fracture Zone, J. Geophys. Res., 89, 10,249-10,266, 1984.

Crane, $K$., The spacing of ridge-axis highs: Dependence upon diapiric processes in the underlying asthenosphere?, Earth Planet. Sci. Lett., 72, 405-414, 1985.

Davis, G. A., and G. S. Lister, Detachment faulting in continental extension: Perspectives from the southwestern U.S. Cordillera, Spec. Pap. Geol. Soc. Am, 218, 133-159, 1988.

Detrick, R. S., J. C. Mutter, P. Buhl, and I. I. Kim, No evidence from multichannel reflection data for a crustal magma chamber in the MARK area on the Mid-Atlantic Ridge, Nature, 347, 61-64, 1990.

Detrick, R. S., R. S. White, and G. M. Purdy, Crustal structure of North Atlantic fracture zones, Rev. Geophys., 31, 439-458, 1993. 
Dick, H. J. B., Abyssal peridotites, very slow spreading ridges and ocean ridge magmatism, in Magmatism in the Ocean Basins, edited by A. D. Saunders and M. J. Norry, Geol. Soc. Spec. Publ. London, 42, 71-105, 1989.

Dick, H. J. B., W. B. Bryan, and G. Thompson, Low-angle faulting and steady-state emplacement of plutonic rocks at ridge-transform intersections, Eos Trans. AGU, 62, 406, 1981.

Dick, H. J. B., H. Schouten, P. S. Meyer, D. G. Gallo, H. Bergh, R. Tyce, P. Patriat, K. T. M. Johnson, J. Snow, and A. Fisher, Tectonic evolution of the Atlantis II Fracture Zone, Proc. Ocean Drill. Program Sci. Results, 118, 359-398, 1991.

Engel, C. G., and R. L. Fisher, Granitic to ultramafic rock complexes of the Indian Ocean ridge system, western Indian Ocean, Geol. Soc. Am. Bull., 86, 1553-1578, 1975.

Fisher, R. L., H. J. B. Dick, J. H. Natland, and P. S. Meyer, Maficultramafic suites of the slowly spreading Southwest Indian Ridge: PROTEA exploration of the Antarctic plate boundary, $24^{\circ} \mathrm{E}-47^{\circ} \mathrm{E}$, Ofioliti, 11, 147-178, 1986.

Fox, P. J., and D. G. Gallo, A tectonic model for ridge-transform-ridge plate boundaries: Implications for the structure of oceanic lithosphere, Tectonophysics, 104, 205-242, 1984.

Fox, P. J., and D. G. Gallo, The geology of North Atlantic transform plate boundaries and their aseismic extensions, in The Geology of North America, vol. M, The Westem North Atlantic Region, edited by P. R. Vogt and B. E. Tucholke, pp. 157-172, Geological Society of America, Boulder, Colo., 1986.

Fox, P. J., and D. G. Gallo, Transforms of the eastern central Pacific, in The Geology of North America, vol. N, The Eastem Pacific Ocean and Hawaii, edited by E. L. Winterer, D. M. Hussong, and R. W. Decker, pp. 111-124, Geological Society of America, Boulder, Colo., 1989.

Fox, P. J., W. C. Pitman III, and F. Shephard, Crustal plates in the central Atlantic: Evidence for at least two poles of rotation, Science, 165, 487-489, 1969.

Fox, P. J., R. S. Detrick, and G. M. Purdy, Evidence for crustal thinning near fracture zones: Implications for ophiolites, in Ophiolites: Proceedings International Ophiolite Symposium, Cyprus 1979, pp. 161-168, Cyprus Geological Survey Department, Nicosia, 1980.

Francis, T. J. G., Serpentinization faults and their role in the tectonics of slow spreading ridges, J. Geophys. Res., 86, 11,616-11,622, 1981.

Gente, P., L. P. Zonenshain, M. I. Kuzmin, A. P. Lisitsin, Y. A. Bogdanov, and B. V. Baranov, Geology of the axis of the MidAtlantic Ridge between $23^{\circ} \mathrm{N}$ and $26^{\circ} \mathrm{N}$ : Preliminary results of the 15th cruise of R/V Akademik Mstislav Keldysh (March-April 1988), C. R. Acad. Sci. Ser. 2, 308, 1781-1788, 1989.

Gente, P., C. Mevel, J. M. Auzende, J. A. Karson, and Y. Fouquet, An example of a recent accretion on the Mid-Atlantic Ridge: The Snake Pit neovolcanic ridge (MARK area, $2^{\circ}{ }^{\circ} 2 \mathrm{~N}$ ), Tectonophysics, 190, 1-29, 1991.

Hussong, D. M., P. B. Fryer, J. D. Tuthill, and L. K. Wipperman, The geological and geophysical setting near DSDP Site 395, North Atlantic Ocean, Initial Rep. Deep Sea Drill. Proj., 45, 23-37, 1979.

Karson, J. A., Seafloor spreading on the Mid-Atlantic Ridge: Implications for the structure of ophiolites and oceanic lithosphere produced slow-spreading environments, in Proceedings of the Symposium TROODOS 1987, edited by J. Malpas et al., pp. 547-555, Geological Survey Department, Nicosia, Cyprus, 1990.

Karson, J. A., and H. J. B. Dick, Tectonics of ridge-transform intersections at the Kane Fracture Zone, Mar. Geophys. Res., 6, 51-98, 1983.

Karson, J. A., and H. J. B. Dick, Deformed and metamorphosed oceanic crust on the Mid-Atlantic Ridge, Ofioliti, 9, 279-302, 1984.

Karson, J. A., et al., Along-axis variations in seafloor spreading in the MARK area, Nature, 328, 681-685, 1987.

Klitgord, K. D., and H. Schouten, Plate kinematics of the central Atlantic, in The Geology of North America, vol. M, The Western North Atlantic Region, edited by P. R. Vogt and B. E. Tucholke, pp. 351-378, Geological Society of America, Boulder, Colo., 1986.

Kuo, B.-Y., J. Phipps Morgan, and D. W. Forsyth, Asymmetry in topography of the crestal mountains near a ridge-transform intersection, Eos Trans. AGU, 65, 274, 1984.

Kuo, B. Y., and D. W. Forsyth, Gravity anomalies of the ridge-transform system in the South Atlantic between 31 and $34.5^{\circ} \mathrm{S}$ : Upwelling centers and variations in crustal thickness, Mar. Geophys. Res., 10, 205-232, 1988.

Lagabrielle, Y., and M. Cannat, Alpine Jurassic ophiolites resemble the modern central Atlantic basement, Geology, 18, 319-322, 1990.

Lin, J., and J. Phipps Morgan, The spreading rate dependence of threedimensional mid-ocean ridge gravity structure, Geophys. Res. Lett., 19, 13-16, 1992.

Lin, J., G. M. Purdy, H. Schouten, J.-C. Sempere, and C. Zervas, Evidence from gravity data for focused magmatic accretion along the Mid-Atlantic Ridge, Nature, 344, 627-632, 1990.

Lin, J., B. E. Tucholke, and M. C. Kleinrock, Off-axis "boudin-shaped" gravity lows on the western flank of the Mid-Atlantic Ridge at $25^{\circ} 25^{\prime}-27^{\circ} 10^{\prime} \mathrm{N}$ : Evidence for long-term pulses in magmatic accretion in spreading segments (abstract), Eos Trans. AGU, 74 (16), Spring Meeting suppl., 380, 1993.

Louden, K. E., and D. W. Forsyth, Crustal structure and isostatic compensation near the Kane Fracture Zone from topography and gravity measurements, I, Spectral analysis approach, Geophys. J. $R$. Astron. Soc., 68, 725-750, 1982.

Macdonald, A. H., and W. S. Fyfe, Rate of serpentinization in seafloor environments, Tectonophysics, 116, 123-135, 1985.

Macdonald, K. C., The crest of the Mid-Atlantic Ridge: Models for crustal generation processes and tectonics, in The Geology of North America, vol. $M$, The Westem North Atlantic Region, edited by P. R. Vogt and B. E. Tucholke, pp. 51-68, Geological Society of America, Boulder, Colo., 1986.

Macdonald, K. C., D. S. Scheirer, and S. M. Carbotte, Mid-ocean ridges: Discontinuities, segments and giant cracks, Science, 253, 986-994, 1991.

Madsen, J. A., R. S. Detrick, J. C. Mutter, P. Buhl, and J. A. Orcutt, A two- and three-dimensional analysis of gravity anomalies associated with the East Pacific Rise at $9^{\circ} \mathrm{N}$ and $13^{\circ} \mathrm{N}, J$. Geophys. Res., 95, 4967-4987, 1990.

Menard, H. W., and T. M. Atwater, Changes in direction of sea floor spreading, Nature, 219, 463-467, 1968.

Mevel, C., M. Cannat, P. Gente, E. Marion, J. M. Auzende, and J. A. Karson, Emplacement of deep crustal and mantle rocks on the west median valley wall of the MARK area (MAR, $23^{\circ} \mathrm{N}$ ), Tectonophysics, 190, 31-53, 1991.

Minshull, T. A., R. S. White, J. C. Mutter, P. Buhl, R. S. Detrick, C. A. Williarns, and E. Morris, Crustal structure at the Blake Spur Fracture Zone from expanding spread profiles, J. Geophys. Res., 96, 99559984, 1991.

Miyashiro, A., F. Shido, and M. Ewing, Composition and origin of serpentinites from the Mid-Atlantic Ridge near $24^{\circ}$ and $30^{\circ}$ north latitude, Contrib. Mineral. Petrol., 23, 117-127, 1969.

Morris, E., and R. S. Detrick, Three-dimensional analysis of gravity anomalies in the MARK area, Mid-Atlantic Ridge $23^{\circ} \mathrm{N}$, J. Geophys. Res., 96, 4355-4366, 1991.

Morris, E., R. S. Detrick, T. A. Minshull, J. C. Mutter, R. S. White, W. Su, and P. Buhl, Seismic structure of oceanic crust in the western North Atlantic, J. Geophys. Res., 98, 13,879-13,903, 1993.

Müller, R. D., and W. R. Roest, Fracture zones in the North Atlantic from combined Geosat and Seasat data, J. Geophys. Res., 97, 33373350, 1992.

Mutter, J. C., and J. A. Karson, Structural processes at slow-spreading ridges, Science, 257, 627-634, 1992.

Mutter, J. C., and NAT Study Group, Multichannel seismic images of the oceanic crust's internal structure: Evidence for a magma chamber beneath the Mesozoic Mid-Atlantic Ridge, Geology, 13, 629-632, 1985.

O'Hara, M. J., Mineral facies in ultrabasic rocks, in Ultramafic and Related Rocks, edited by P.J. Wyllie, pp. 7-18, John Wiley, New York, 1967. 
OTTER, The geology of the Oceanographer transform: The ridgetransform intersection, Mar. Geophys. Res., 6, 109-141, 1984.

Pariso, J.E., and H.P. Johnson, Do layer 3 rocks make a significant contribution to marine magnetic anomalies? In situ magnetization of gabbros at Ocean Drilling Program Hole 735B, J. Geophys. Res., 98, $16,033-16,052,1993$.

Parsons, B., and J. G. Sclater, An analysis of the variation of ocean floor bathymetry and heat flow with age, J. Geophys. Res., 82, 803-827, 1977.

Phillips, J. D., and H. S. Fleming, Multibeam sonar study of the Mid-Atlantic Ridge rift valley $36^{\circ}-37^{\circ} \mathrm{N}$, Geol. Soc. Am. Bull., 88, 1-5, 1977.

Phipps Morgan, J., and D. W. Forsyth, Three-dimensional flow and temperature perturbations due to a transform offset: Effects on oceanic crustal and upper mantle structure, J. Geophys. Res., 93, 2955-2966, 1988.

Pockalny, R. A., R. S. Detrick, and P. J. Fox, Morphology and tectonics of the Kane transform from Sea Beam bathymetry data, J. Geophys. Res., 93, 3179-3193, 1988.

Pockalny, R. A., and P. Gente, A model for the segmentation characteristics of a slowly spreading mid-ocean ridge (abstract), Eos Trans. $A G U, 73$ (43), Fall Meeting suppl., 569, 1992.

Prince, R. A., and D. W. Forsyth, Horizontal extent of anomalously thin crust near the Vema Fracture Zone from the three-dimensional analysis of gravity anomalies, J. Geophys. Res., 93, 8051-8063, 1988.

Prinz, M., K. Keil, J. A. Green, A. M. Reid, E. Bonatti, and J. Honnorez, Ultramafic and mafic dredge samples from the equatorial MidAtlantic Ridge and fracture zones, J. Geophys. Res., 81, 4087-4103, 1976.

Purdy, G. M., J.-C. Sempere, H. Schouten, D. L. Dubois, and R. Goldsmith, Bathymetry of the Mid-Atlantic Ridge, $24^{\circ}-31^{\circ} \mathrm{N}$ : A map series, Mar. Geophys. Res., 12, 247-252, 1990.

Rona, P. A., and D. F. Gray, Structural behavior of fracture zones symmetric and asymmetric about a spreading axis: Mid-Atlantic Ridge (lat. $23^{\circ} \mathrm{N}$ to $27^{\circ} \mathrm{N}$ ), Geol. Soc. Am. Bull., 91, 485-494, 1980.

Schouten, H., and R. S. White, Zero-offset fracture zones, Geology, 8 , 175-179, 1980.

Schouten, H., H. J. B. Dick, and K. D. Klitgord, Migration of mid-ocean ridge volcanic segments, Nature, 326, 835-839, 1987.

Searle, R. C., and A. S. Laughton, Sonar studies of the Mid-Atlantic Ridge and Kurchatov Fracture Zone, J. Geophys. Res., 82, 53135328, 1977.

Severinghaus, J. P., and K. C. Macdonald, High inside corners at ridgetransform intersections, Mar. Geophys. Res., 9, 353-367, 1988.

Shipboard Scientific Party, Site 395: 23N, Mid-Atlantic Ridge, Initial Rep. Deep Sea Drill. Proj., 45, 131-264, 1979.

Shipboard Scientific Party, Site 670, Proc. Ocean Drill. Program, Pant A, Initial Rep., 109, 203-237, 1988.

Sloan, H., and P. Patriat, Kinematics of the North American--African plate boundary between $28^{\circ}$ and $29^{\circ}$ during the last $10 \mathrm{Ma}$ : Evolution of the axial geometry and spreading rate and direction, Earth Planet. Sci. Lett., 113, 323-341, 1992.

Smith, D. K., and J. R. Cann, The role of seamount volcanism in crustal construction at the Mid-Atlantic Ridge $\left(24^{\circ}-30^{\circ} \mathrm{N}\right)$, J. Geophys. Res., 97, 1645-1658, 1992

Smith, D. K., and J. R. Cann, Building the crust at the Mid-Atlantic Ridge, Nature, 365, 707-715, 1993.

Sparks, D. W., E. M. Parmentier, and J. Phipps Morgan, Three-dimensional mantle convection beneath a segmented spreading center: Implications for along-axis variations in crustal thickness and gravity, J. Geophys. Res., 98, 21,977-21,995, 1993.

Srivastava, S. P., H. Schouten, W. R. Roest, K. D. Klitgord, L. C. Kovacs, J. Verhoef, and R. Macnab, Iberian plate kinematics: A jumping plate boundary between Eurasia and Africa, Nature, 344, 756-759, 1990.

Tiezzi, L. J., and R. B. Scoft, Crystal fractionation in a cumulate gabbro, Mid-Atlantic Ridge, 26º, J. Geophys. Res., 85, 5438-5454, 1980.

Tricart, P., and M. Lemoine, The Queyras ophiolite west of Monte Viso (Western Alps): Indicator of a peculiar ocean floor in the Mesozoic Tethys, J. Geadyn, 13, 163-181, 1991.

Tucholke, B. E., and J. Lin, Asymmetric crustal structure at ridge-axis offsets, Mid-Atlantic Ridge (abstract), Eos Trans. AGU, 72 (44), Fall Meeting suppl., 467, 1991.

Tucholke, B. E., and J. Lin, Detachment faulting and its relation to geologic structure at first- and second-order offsets of slow-spreading ridges (abstract), Eos Trans. AGU, 73 (14), Spring Meeting suppl., 286, 1992.

Tucholke, B. E., and H. Schouten, Kane Fracture Zone, Mar. Geophys. Res., 10, 1-39, 1988.

Wernicke, B., Low-angle normal faults in the Basin and Range Province: Nappe tectonics in an extending orogen, Nature, 291, 645648, 1981.

White, R. S., R. S. Detrick, M. C. Sinha, and M. H. Cormier, Anomalous seismic crustal structure of oceanic fracture zones, Geophys. J. R. Astron. Soc., 79, 779-798, 1984.

White, R. S., R. S. Detrick, J. C. Mutter, P. Buhl, T. A. Minshull, and E. Morris, New seismic images of oceanic crustal structure, Geology, $18,462-465,1990$.

Whitehead, J. A., H. J. B. Dick, and H. Schouten, A mechanism for magmatic accretion under spreading centers, Nature, 312, 146-148, 1984.

Zervas, C., J. Lin, and P. Rona, Asymmetric V-shaped gravity stripes at the Mid-Atlantic Ridge $26^{\circ} \mathrm{N}$ (abstract), Eos Trans. AGU, 71, 1572, 1990.

Zonenshain, L. P., M. I. Kuzmin, A. P. Lisitsin, Y. A. Bogdanov, and B. V. Baranov, Tectonics of the Mid-Atlantic rift valley between the TAG and MARK areas (26-24 $\mathrm{N}$ ): Evidence for vertical tectonism, Tectonophysics, 159, 1-23, 1989.

J. Lin and B. E. Tucholke, Department of Geology and Geophysics, Woods Hole Oceanographic Institution, Woods Hole, MA 02543 (email: Internet jlin @whoi.edu; btucholke@whoi.edu)

(Received May 3, 1993; revised January 24, 1994; accepted January 31, 1994.) 